\title{
Orta Gelir Tuzağı: Üst Orta Gelirli Ülkeler Üzerine Panel Veri Analizi
}

\author{
Middle Income Trap: Panel Data Analysis on Upper Middle Income Countries
}

Eda BOZKURT, ${ }^{1}$ Haktan SEVINÇ ${ }^{2}$, Erol ÇAKMAK ${ }^{3}$

\begin{abstract}
ÖZET
Çalışmanın amacı, seçilmiş bir grup üst orta gelirli ülke örneği üzerinden, yakınsama ve panel veri analizleriyle 1982-2012 dönemi için orta gelir tuzağının gerçekleşme ihtimali ve bu durumdan kaçınmada etkili olabilen sosyal ve ekonomik göstergelerin ortaya konulmasıdır. Koşulsuz yakınsama analizleri, ilgili ülke grubunun başlangıç kişi başına düşen gelir düzeylerinin süreç boyunca artırmış olduklarını ortaya koymuştur. Birim kök analizine dayalı yakınsama analizleri ile ülkelerin bireysel performansları araştırılmış, bunlardan $15^{\prime}$ inin yüksek gelirli ülkelere yakınsarken, kalan 13 ülkenin ıraksadıkları belirlenmiştir. Panel veri sonuçları ise sadece ıraksayan ülkelerin değil aynı zamanda Türkiye'nin de içinde bulunduğu yakınsayan ülkelerin yapısal dönüşüm sürecine ayak uyduramadıkları takdirde orta gelir tuzağına takılma ihtimalinin yüksek olduğunu göstermiştir. Araştırma sonuçları, bu durumun tek başına ülkelerin kişi başına düşen gelirindeki nicel artışa değil, aynı zamanda ekonomilerdeki yapısal değişiklik düzeyine bağlı olduğu sonucunu ortaya koymuştur.
\end{abstract}

Anahtar Kelimeler: Orta Gelir Tuzağı, Yakınsama Hipotezi, Panel Veri Analizi

\begin{abstract}
The purpose of the dissertation is to put forward the possibility of middle income trap and the social and economic indicators to help avoid it for a selected group of upper middle income countries by employing convergence and panel data analyses during the period of 1982-2012. Unconditional convergence analysis demonstrated that initial per capita income level of relevant country group increased during the period. Country performances are separately analyzed through unit root analysis and it was shown that 15 of the countries converged to the high income countries while the rest 13 diverged. Panel data analyses resulted that the possibility of middle income trap are high not only for countries which are diverged but also for converged ones, among which Turkey is listed provided that those countries failed to keep up with structural change in their economies. The results of empirical analyses put forward that the risk of middle income trap depends on not only the quantitative increases in per capita income but also the level of structural change in the economy.
\end{abstract}

Key Words: Middle Income Trap, Convergence Hypothesis, Panel Data Analysis

\section{GíRiş}

Dünya ekonomisinin son yarım yüzyılı boyunca orta gelirli ülke grubunda bulunan ülkelerin çok azı yüksek gelirli ülke grubuna yükselebilmiştir. Ülkelerin uzun bir süre zarfında orta gelir kategorisinde kalıp yüksek gelir kategorisine geçememeleri durumu, ekonomi literatürüne yeni giren "orta gelir tuzağı"(OGT) kavramı ile tanımlanmaktadır. OGT; iktisatta temelleri açık bir şekilde ortaya konulmuş bir hipotez olmamakla birlikte, özellikle gelişmekte olan ülkelerin maruz kalabileceği tıkanıklıklardan birini oluşturan ve iktisat literatüründe giderek daha

fazla kabul gören bir durumdur. OGT isim olarak araştırmacıların karşısına yeni bir formla çıkmış olsa dahi alternatif kullanımları olan büyüme yavaşlaması, büyüme yorgunluğu ve durağan büyüme gibi terimlerle iktisatçıların aşina olduğu bir konuya daha farklı bir bakış açısı getirmektedir. OGT; düşük ücretli fakir ülkelere karşı standart imalat sanayi ürünlerinde rekabet gücünü zayıflayan ve yeniliğe dayalı büyüyen zengin ülkelere göre yakınsamakta zorlanan ülkelerin maruz kaldığı bir durumdur (World Bank, 2007;1718). Bu bağlamda OGT'nin kuramsal kökenleri genel olarak Solow'un (1956) önderliğindeki Neoklasik 
Büyüme Teorisine dayanmaktadır. Neoklasik Teori, teknoloji ve emeği sabit sayarken, sermaye birikiminin önündeki en önemli engeli azalan getiri oranları olarak kabul etmektedir. Sermaye birikimine dayalı bir üretim modeli, nihayetinde sıfır büyüme ile dengelenmekte ve sonuçta durağan durum ya da OGT'nin oluşumu ile karşılaşılmaktadır. Fakat sadece fiziksel sermaye birikimine dayalı bir büyüme modelinin sürdürülebilir nitelikte olmadığı artık bilinen bir gerçektir, iktisadi büyüme eğitim ve araştırma-geliştirmeye dayalı sermaye birikimi ile desteklenmelidir (Yeldan vd. 2012; 33). Işste bu noktada küresel düzeyde ülkelerin performanslarıyla ilgili olan OGT'nin anlaşılması, önlemler oluşturulması ve aşılması tek başına gelir artışı sağlamanın yanında gelişmiş ülke olabilmenin gerekçesi haline gelmiştir. Bu bağlamda OGT üzerine yapılan çalışmalardan biri Aoki (2011) tarafından gerçekleştirilmiştir. Doğu Asya ülkelerinden Çin, Japonya ve Güney Kore'nin ele alındığı çalışmada ekonomik gelişmenin beş safhası olduğunu belirlenmiştir. M-evresi (Malthusyen evre), G-evresi (hükümet odaklılık), K-evresi (Kuznets Evresi ya da Lewis Evresi), H-evresi (beşeri sermayeye dayalılık), PD-evresi (demografik geçiş sonrası)'dir. Bu evreler toplam istihdam edilen nüfustaki ekonomik ve demografik değişim, yapısal geçiş ve toplam faktör değişiklikleri ile hesaplanmıştır. Çalışma bulgularına göre Çin bu evrelerden H-evresine dönüşüm içindedir. Güney Kore H-evresi içinde, Japonya ise PDevresindedir. Çin'in OGT ile ilgili kaderi H-evresin kalış sürecindeki evrilme başarısına bağlıdır. Çünkü beşeri sermaye faktör verimliliğinin ana kaynağıdır. Felipe vd. (2012), 1950-2010 döneminde 124 ülkeyi dört gruba ayırarak tarihsel olarak gelir geçişlerini, süreleri ve büyüme hızlarını araştırmışlardır. Araştırmaya göre, kişi başına düşen GSYiH (gayrisafi yurtiçi hasıla) 2.000 dolardan az olanlar düşük gelirli, 2.000 ile 7.250 dolar arasında olanlar alt orta gelirli, 7.250 ile 11.750 dolar arasında olanlar üst orta gelirli ve 11.750 dolardan fazla olanlar yüksek gelirli ülke grubundadır. Ülkelerin alt orta gelir tuzağından kurtulması için kişi başına düşen gelirin yıllık en az \%4,7 ve üst orta gelir tuzağından kaçınmaları için en az \%3,5 büyümesi gerekli eşik değerdir. Ayrıca ülkelerin en fazla 28 yıl içinde alt orta gelir grubundan ve en fazla 14 yıl içinde üst orta gelir grubundan yukarı çıkmaları gerekmektedir. Aksi takdirde söz konusu zaman zarfında gelişmeyen ülkeler OGT'ye takılmış olurlar. $\mathrm{Bu}$ araştırmaya göre Türkiye 50 sene alt orta gelir grubunda kalmıştır ve ortalama yıllık büyüme oranı \%2,6 olmuştur. Ayrıca OGT'nin bir büyüme meselesi olduğu fikrine dayalı bir diğer çalışma Eichgreen vd. (2013) tarafından gerçekleştirilmiştir. Çalışmada 1957-2007 döneminde 45 ülke için ve ChowProbit Testleri ile OGT analizi yapılmıştır. Araştırma bulguları sonucunda OGT'nin 10.000-11.000 ve 15.000-16.000 dolarla iki seviyede oluşabileceği savunulmuştur. OGT'den kurtulmak için en etkili faktörlerin beşeri sermaye ve yüksek teknolojili ürünlerin ihracat içindeki payının artırılması olduğu tespit edilmiştir. Diğer taraftan siyasal rejim yani demokratikleşme ile yavaşlama olasılığı arasında anlamlı bir ilişki saptanmıştır. Aiyar vd. (2013), OGT'nin belirleyicilerini 1955-2009 dönemini kapsayan 11 dönem için seçilmiş Asya ve Latin Amerika ülkeleri bazında incelemişlerdir. Çalışmada Probit Regresyonu, Bayesian ve Ağırlıklandırımış En Küçük Kareler Modeli kullanılmıştır. Kişi başına düşen GSYiH yıllık büyüme oranının kurumlar, demografi, altyapı, makroekonomik ortam ve politikalar, üretim yapısı, ticaret yapısı ve diğer değişkenler ile ilişkisi araştırılmıştır. OGT'de en önemli değişkenlerin gayrisafi sermaye girişlerindeki ani azalmalar ve çıkışlar ile zayıf ihracat çeşitliliği olduğu belirlenmiştir. 2013 yılında gerçekleştirilen bir başka çalışmada ise Robertson ve Longfeng, OGT'yi stokastik ve yapısal kırılma testleri ile incelemişlerdir. Kişi başına düşen GSYiH değerlerini birim kök testlerinden Genişletilmiş Dickey-Fuller, Zivot-Andrews ve Lumsdaine ve Papell testleri kullanarak açıklamışlardır. 189 ülkenin 46'sının orta gelirli ve 23'ünün OGT'de olduğu sonucuna ulaşmışlardır. Türkiye temelli çalışmalardan ise örneğin, Yeldan vd. (2012), OGT ışığında Türkiye ekonomisini makro, bölgesel ve sektörel açıdan değerlendirilmişlerdir. Öncelikle büyüme muhasebesi yöntemiyle toplam faktör verimlilikleri hesaplanmıştır. Yapılan analizler çerçevesinde Türkiye, OGT açısından üç farklı bölgeye ayrılmıştır. Birincisi OGT'nin olmadığı gelişmiş ve sanayileşmiş bölgeler, ikincisi OGT riskinin olduğu bölgeler, üçüncüsü ise OGT'nin ve yoksulluk riskinin olduğu bölgelerdir. Gürsel ve Soybilgen (2013) Türkiye'de kişi başına düşen gelirin bileşenlerini 2005(1)2013(1) dönemi için incelemişlerdir. Türkiye'de nüfus artışına bağlı olarak çalışabilir nüfusun arttığı fakat önümüzdeki dönemde çalışabilir nüfus artışının yavaşlayarak 2030'larda sıfırlanacağı ve demografik fırsat penceresinin kapanacağı tespit edilmiştir. Türkiye'nin OGT'ye düşmesini engelleyecek esas etkenin emek verimliliği olduğu; verimlilik artışlarının ise başta eğitim sistemi olmak üzere işgücü piyasası, 
vergi sistemi, enerji piyasası gibi alanlardaki yapısal reformlarla sağlanacağı vurgulanmışlardır.

$\mathrm{Bu}$ çalışmanın temel amacl; gelişmekte olan ülkelerin ekonomik büyüme yolunda karşılaşabilecekleri OGT'nin, ülkelerin ekonomik gelişme düzeyleri üzerindeki kritik öneminden hareketle üst orta gelir grubundaki seçilmiş bir grup ülkenin yüksek gelirli ülkelere yakınsayıp yakınsamadıklarını ortaya koymaktır. Ayrıca gelir yakınsamasının, OGT'ye düşme ya da düşmeme konusunda tek başına belirleyici olamayacağı konusundaki teorik bilgilerden hareketle, OGT üzerinde etkili olabilecek kalkınma göstergelerini tespit etmektir. Bu amaçla, çalışmada öncelikle seçilmiş bir grup üst orta gelirli ülke için yatay-kesit analizine dayalı koşulsuz gelir yakınsaması analizi yapılmıştır.' Ardından her bir ülkenin bu konudaki durumunu tespit etmek için, bu ülkelerin yüksek gelirli ülkelerle bir gelir yakınsaması içinde olup olmadıkları birim kök testine dayalı yakınsama analizi ile incelenmiştir. Daha sonra gelir yakınsaması ya da ıraksamasının bir OGT sinyali olabileceği kabulünden hareketle, OGT'ye düşmemeyi sağlayabilecek ekonomik ve sosyal göstergeler belirlenmiştir. Söz konusu bu göstergeler, uluslararası literatürde genel kabul görmüş değişkenlerdir. ${ }^{2}$ Uygulamanın bu bölümünde, panel birim kök ve panel eş-bütünleşme analizleri kullanılmıştır.

\section{VERI SETI ve YÖNTEM}

Uygulama kapsamında Dünya Bankası'nın yaptığı kişi başına düşen milli gelir sınıflandırmasına göre belirlenen bir grup üst orta gelirli ülke ele alınmıştır. Dünya Bankası'nın Atlas Metodu sınıflamasına göre tüm üst orta gelirli ülkelerin analiz kapsamında tutulması hedeflenmiştir. Fakat grup içerisinde yer alan bazı ülkelere ait verilerin mevcut olmaması veya kesik olması dolayısıyla üst orta gelirli ülkeleri temsilen 28 ülkenin kullanılmasını zorunlu kılmıştır. 1982-2012 yıllarını içine alan 31 yıllık dönemi kapsamaktadır. Çalışmada kullanılan panelin, 19822012 dönemini kapsayan 31 yıllık zaman boyutu (T), 28 üst orta gelirli ülkeyi kapsayan yatay kesit boyutu (N)'ndan büyüktür.

Çalışmada yakınsama analizi, en küçük kareler tahmin yöntemine dayalı mutlak $\beta$ yakınsaması ve birim kök testleriyle gerçekleştirilmiştir. Çalışma kapsamındaki analizler için Barro ve Sala-i Martin (1992) tarafından geliştirilen mutlak $\beta$ yakınsaması eşitliği esas alınmıştır. Bu bağlamda yakınsama analizi için temel alınan model aşağıdaki gibidir:

$$
\frac{1}{\mathrm{~T}} \mathrm{x} \log \left(\frac{\mathrm{y}_{\mathrm{i}, \mathrm{t}_{0}+\mathrm{T}}}{\mathrm{y}_{\mathrm{i}, \mathrm{t}_{0}}}\right)=\beta-\log \left(\frac{1-\mathrm{e}^{-\beta \mathrm{T}}}{\mathrm{T}}\right) \log \left(\mathrm{y}_{\mathrm{i}, \mathrm{t}_{0}}\right)+\mathrm{u}_{\mathrm{i}, \mathrm{t}_{0}, \mathrm{t}_{0}+\mathrm{T}}
$$

(1) nolu modelde T, zaman aralığını; $y_{i, t_{0}+T}$ i ülkesinde $\mathrm{t}$ yılındaki kişi başına geliri; $y_{i, t_{0}}$, i ülkesinin başlangıç yılındaki kişi başına gelirini ve $u_{i, t_{0}, t_{0}+T}$, hata terimini göstermektedir. $\beta$ ise mutlak yakınsama katsayısı olup istatistiki olarak anlamlı olmak şartıyla $\beta<0$ olduğu durumlarda, mutlak yakınsamanın varlığını işaret etmektedir. Aksine $\beta>$ 0 veya $\beta=0$ olduğu hallerde mutlak yakınsamanın gerçekleşmediği sonucuna varılmaktadır.

Öte yandan uygulamalı literatürde $\beta$ yakınsaması dışında, yakınsamanın varlığının test edilmesine yönelik olarak geliştirilen birtakım yöntemler bulunmaktadır. Bu yöntemlerden biri, kişi başına gelir serilerinin durağan olup olmamasına göre yakınsama olgusunun araştırıldığı zaman serisi analizidir. Bu yaklaşımda şayet seriler durağansa, verilerin uzun dönemde ortalamalara yönelmesinden dolayı yakınsamanın gerçekleştiği kabul edilmektedir. Durağan olmayan seriler de ise meydana gelen şoklar sonucunda ortalamadan uzaklaştığı ve seriler arasında ıraksamanın oluştuğu ileri sürülmektedir. Zaman serisi verilerine dayalı bu yakınsama analizi, panel verilere dayalı olarak yapılabilmektedir. Bu durumda yakınsama hipotezi panel birim kök testleri ile test edilmektedir (Nahar ve Inder, 2002;2012-2013).

Literatürdeki uygulamalardan hareketle bu çalışma da yakınsama hipotezi birim köke dayalı panel yakınsama analizi ile tahmin edilmiştir. Tahmin için Nahar ve Inder (2002) tarafından yapılan çalışmada kullanılan denklem esas alınmıştır. Söz konusu denklem aşağıdaki gibidir.

$$
\lim _{n \rightarrow \infty} E\left(Y_{i, t+n}-a_{t+n}\right)=\mu_{i}
$$

(2) nolu denklemde $a_{t+n}$ en iyi performansa sahip ülkenin (ülkelerin) verisini temsil etmektedir. Söz konusu model kullanılarak yapılan çok ülkeli analizlerde yakınsama daha çok örneklem

'Solow Modeli'nde öngörülen koşulsuz beta yakınsaması başlangıçta düşük gelir düzeyine sahip ülkelerin kişi başına düşen gelirlerini daha hızlı artıracağına işaret etmektedir.

${ }^{2}$ Analizde kullanılan değişkenler Aiyar vd. (2013), Eichengreen vd. (2013), Robertson ve Ye (2013) çalışmaları ışığında tespit edilmiştir. 381 
ortalamasından sapmalarla ölçülmektedir. Serilerin birim kök içermemesi, yani serilerin durağan olması yakınsamanın varlığına işaret olarak kabul edilirken, serilerin birim kök içermesi yakınsamanın olmadığını ifade etmektedir.

Çalışmanın uygulama kısmında kullanılan ikinci yöntem ise panel veri analizidir. Panel veri analizleri

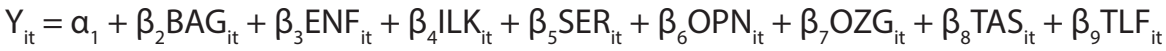

Bağımlı değişken ( $\mathrm{Y}$ ) olarak kullanılan kişi başına düşen GSYIH verileri, 2005 yılı fiyatlarına göre dolar cinsinden ifade edilmiştir. Bağımsız değişkenler ise hem ekonomik hem de sosyo-politik göstergelerden oluşmaktadır. Fakat ülke seçiminde olduğu gibi değişkenlerin seçimlerinde de veri yetersizliği sebebiyle literatürde kullanılmış uygun değişkenlerde bir takım farklııkların yapılması zorunlu hale gelmiştir. Örneğin beşeri sermayeyi temsilen yüksek eğitimde okullaşma oranı yerine ilköğretimde okullaşma oranı; yüksek teknolojili ürünlerin ihracatı yerine dışa açıklık göstergesi seçilmiştir.

BAG; bağımlılık oranı, çalışma çağı dışındaki nüfusun (0-14 ve 65 + yaş) çalışma çağındaki nüfusa (15-64 yaş) oranını göstermektedir. ENF; enflasyon oranı, 2005 baz yıllı TÜFE'ye göre hesaplanmıştır. Beşeri sermayeyi temsilen ilköğretimde okullaşma oranı (ILK) kullanılmıştır. SER; sabit sermaye stoku/ GSYiH ve TAS; yurtiçi tasarruf/GSYiH, 2005 yılı baz fiyatlarına göre milyon dolar cinsinden temin edilen sabit sermaye stoku ve yurtiçi tasarrufların GSYiH içindeki paylarını göstermektedir. OPN; dışa açıklık oranı, yüksek teknolojili ürün ihracatının

$$
Y_{i t}=\alpha_{i+} \beta_{i} X_{i t}+\varepsilon_{i t} \quad i=1 \ldots \ldots N, \quad t=1 \ldots \ldots T
$$

(4) nolu denklemin tahmini için kullanılan hipotezler; $\mathrm{H}_{0}: \beta_{\mathrm{i}}=\beta$ Eğim katsayıları homojendir (bütün $\beta i$ 'ler için) ve $\mathrm{H} 1: \beta i \neq \beta$ Eğim katsayıları homojen değildir (en az bir i için) şeklindedir.

Söz konusu hipotezlerin test edilmesi için kullanılan Delta Test istatistiği $\hat{\Delta}=\sqrt{\mathrm{N}}\left(\frac{\mathrm{NS}^{\wedge}-\mathrm{k}}{\sqrt{2 \mathrm{k}}}\right)$ eşitliği ile hesaplanmaktadır. $\tilde{\Delta}$ olarak ifade edilen düzeltilmiş delta test istatistiği ise $\tilde{\Delta}=\sqrt{\hat{N}}\left(\frac{N^{\sim}-E\left(\tilde{z}_{\bar{z}}\right.}{\sqrt{\operatorname{Var} \tilde{z}_{n}}}\right)$ denklemi ile belirlenmektedir. Tahminlenen olasılık değeri istatistiki olarak anlamlı ise $\mathrm{H}_{0}$ hipotezi reddedilmekte ve eğim katsayılarının heterojen olduğuna karar verilmektedir. Birim kök ve eş-bütünleşme testlerinin seçiminde önemli olan bir diğer unsur ise yatay kesit bağımlılığının (cross-section dependence) varlığının homojenlik, yatay kesit bağımlılığı, panel birim kök ve eş-bütünleşme testleri ve eş-bütünleşme katsayılarını tahmin etmek amacıyla regresyon analizlerinden oluşmaktadır. Regresyon analizleri için konu ile ilgili uygulamalı literatürde birçok araştırmacının yaygın bir şekilde kullandığı model esas alınmıştır. ${ }^{3}$ Eşbütünleşme katsayılarının tahmini için temel alınan regresyon eşitliği aşağıdaki gibidir:

göstergesi olarak kabul edilmiş ve [(ithalat + İhracat)/ GSYiH] formülü kullanılarak hesaplanmıştır. OZG; özgürlük endeksi olarak Freedom House tarafından hazırlanan endeks değeri kullanılmıştır. TLF; telefon ağı, 100 kişi başına düşen sabit telefon hattı sayısını göstermektedir.

Çalışmada öncelikle panel veri literatüründe yer alan birim kök ve eş-bütünleşme testlerinden hangisinin uygulanacağını belirlemek amacıyla homojenlikveyatay kesit bağımlılık testleriyapılmıştır. Böylece değişkenlerin homojen ya da heterojen olmasına ve yatay kesit birimlerinin birbiriyle bağımlı olup olmamalarına göre uygulanacak birim kök ve eşbütünleşme testlerine karar verilmiştir.

Homojenlik testiyle panel veri modellerindeki $\beta$ eğim katsayılarının yatay kesitler arasında farklı olup olmadığı test edilmektedir. Homojenlik testinde Pesaran ve Yamagata tarafından geliştirilen Delta Testi kullanılmaktadır. Test S; Swamy test istatistiği ve $k$; bağımsız değişken sayısı olmak üzere aşağıdaki denklemler yardımıyla hesaplanmaktadır (Pesaran ve Yamagata, 2008;57).

incelenmesidir. Ayrıca yatay kesit bağımlılığı, yatay kesit birimlerin birbirleriyle bağımlı olup olmadıklarını, yani herhangi bir şoktan tüm yatay kesit birimlerinin etkilenip etkilenmediği ile ilgili bilgi vermektedir.

Yatay kesit bağımlılığın tespiti için kullanılan testlerden ilki Breusch-Pagan (1980) Testidir. T > $\mathrm{N}$ durumuna uyan test Breusch-Pagan Lagrange Çarpanı (Lagrange Multiplier-LM) ile türetilmiş bir testtir (Baltagi, 2005; 59). $C_{\mathrm{LM}_{1}}$ olarak gösterilen ve $\mathrm{H}_{0}=$ Yatay kesit bağımlılık yoktur; $\mathrm{H}_{1}=$ Yatay kesit bağımlılık vardır şeklindeki hipotezleri test eden test istatistiği şu şekilde hesaplanmaktadır (Pesaran, 2004; 5). 


$$
\mathrm{CDLM}_{1}=\mathrm{T} \sum_{\mathrm{i}=1}^{\mathrm{N}-1} \sum_{\mathrm{j}=\mathrm{i}+1}^{\mathrm{N}} \hat{\rho}_{\mathrm{ij}}^{2}
$$

(5) nolu eşitlikte $\widehat{\rho}$ bireysel en küçük kareler tahminlerinden elde edilen artıklar arasındaki yatay kesit korelasyonlarının tahminlerini göstermekte ve test $N(N-1) / 2$ serbestlik derecesi ile $X^{2}$ dağılımı sergilemektedir (Güloğlu ve İvrendi, 2010; 17).

$\mathrm{T}>\mathrm{N}$ durumuna uyan diğer bir test ise Pesaran vd. (2008) tarafından geliştirilen sapması düzeltilmiş $C D_{L M}$ (Bias-adjusted $C D_{L M}$ ) testidir. $C D_{L M 1}$ testi, grup ortalaması sıfır fakat bireysel ortalama sıfırdan farklı olduğunda, sapmalı olmaktadır. Bu nedenle test Pesaran vd. tarafından düzeltilmiş ve $\operatorname{CDLM}_{\mathrm{adj}}=\sqrt{\frac{2}{\mathrm{~N}(\mathrm{~N}-1)}} \sum_{\mathrm{i}=1}^{\mathrm{N}-1} \sum_{\mathrm{J}=\mathrm{i}+1}^{\mathrm{N}} \frac{(\mathrm{T}-\mathrm{k}))_{\mathrm{i}}^{2}-\mu_{\mathrm{Tij}}}{\mathrm{v}_{\mathrm{Tij}}} ; \operatorname{CDLM}_{\mathrm{adj}} \rightarrow \mathrm{N}(0,1) \quad$ eşitliği ile hesaplanmıştır (Pesaran vd. 2008;108). Asimptotik olarak normal dağılımlı olan test istatistiği ile $\mathrm{H}_{0}=$ Yatay kesit bağımlılık yoktur; $\mathrm{H}_{1}=$ Yatay kesit bağımlılık vardır hipotezleri test edilmektedir.

Bir diğer yatay kesit bağımlık testi ise Pesaran (2004) tarafından geliştirilen $C_{L M}$ ve $C D_{L M 2}$ testleridir. $\mathrm{N}>\mathrm{T}$ durumunda kullanılan $\mathrm{CD}_{\mathrm{LM}}$ testi; $\operatorname{cDLM}=\sqrt{\frac{2 \mathrm{~T}}{\mathrm{~N} N-1)}}\left(\sum_{\mathrm{i}=1}^{\mathrm{N}-1} \sum_{\mathrm{j}=\mathrm{i}+1}^{\mathrm{N}} \sqrt{T_{\mathrm{i}} \hat{\mathrm{P}}_{\mathrm{ij}}}\right) ; \mathrm{N}(0,1)$ ve $\mathrm{N} \rightarrow \infty$ eşitliği ile hesaplanmaktadır (Pesaran, 2004;9). $C_{\mathrm{LM}_{2}}$ testi ise hem Them de N'nin büyük olduğu durumlarda $(T=N)$ kullanılmaktadır. $\mathrm{H}_{0}=$ Yatay kesit bağımlılık yoktur ile belirlenen test asimptotik olarak normal dağılımlıdır. Test istatistiği; $\operatorname{CDLM}_{2}=\sqrt{\frac{1}{\mathrm{~N}(\mathrm{~N}-1)}} \sum_{\mathrm{i}=1}^{\mathrm{N}-1} \sum_{\mathrm{J}=\mathrm{i}+1}^{\mathrm{N}}\left(\mathrm{T} \hat{\rho}_{\mathrm{ij}}^{2}-1\right) ; \mathrm{T} \rightarrow \infty, \mathrm{N} \rightarrow \infty$ ile hesaplanmaktadır (Pesaran, 2004;5).

$\mathrm{T}>\mathrm{N}$ durumunda panel seriler arasındaki yatay kesit bağımlılığının varlığı $C D_{L M 1}$ ve sapmasıdüzeltilmiş $\mathrm{CD}_{\mathrm{LM}}$ testleri ile kontrol edilmektedir (Yıldırım vd. 2013; 86-87). Bu çalışmada kullanılan panel $\mathrm{T}>\mathrm{N}$ durumuna uymasına rağmen, karşılaştırma yapmak amacıyla yukarıda belirtilen tüm yatay kesit bağımlılık testleri uygulanmıştır.

Çalışmada $\mathrm{T}>\mathrm{N}$ durumuna uyan ve yatay kesit bağımlılığını dikkate alan Pesaran'ın CADF (CrossSectionally Augmented Dickey Fuller-CADF) II. nesil panel birim kök testi uygulanmıştır (Pesaran, vd. 2008; 266).

Pesaran'ın CADF Testi, standart ADF birim kök testinin bireysel serilerin birinci farkları ve gecikme seviyelerinin yatay kesit ortalamalarına göre genişletilmiş halidir (Pesaran, 2007; 267). CADF Testi'nde, ADF regresyonunun birinci farkı birimler arası korelasyonu yok etmektedir. $\mathrm{H}_{0}: \beta_{\mathrm{i}}=0$ Birim kök vardır ve $H_{1}$ : $\beta_{i}<0$ Birim kök yoktur şeklindeki hipotezlerin test edildiği CADF Testi'nde kullanılan temel denklem aşağıdaki gibidir:

$$
\mathrm{y}_{\mathrm{it}}=\left(1-\phi_{\mathrm{i}}\right)_{\mathrm{i}}+\phi_{\mathrm{i}} \mathrm{y}_{\mathrm{i}, \mathrm{t}-1}+\mathrm{u}_{\mathrm{it}}
$$

(6) nolu denklemde $\mathrm{i}=1, \ldots, \mathrm{N} ; \mathrm{t}=1, \ldots, \mathrm{T}$ $u_{i t}=\gamma_{i} f_{t}+\varepsilon_{i t}$ ve 'dir. $f_{t,}$ gözlemlenemeyen ortak etkileri, $\varepsilon_{i t}$ ise bireysel spesifik hataları göstermektedir. $\phi_{1}=1$ olması durumunda $\mathrm{H}_{0}: \beta_{i}=0$ (tüm i'ler için) şeklindedir. Bu durumda CADF Testi'nde kullanılan denklem şu şekilde olmaktadır.

$$
\Delta \mathrm{y}_{\mathrm{it}}=\alpha_{\mathrm{i}}+\beta_{\mathrm{i}} \mathrm{y}_{\mathrm{i}, \mathrm{t}-1}+\varepsilon_{\mathrm{it}}
$$
nolu denklemde $\alpha_{\mathrm{i}}=\left(1-\phi_{\mathrm{i}}\right) \mu_{\mathrm{i}}, \beta_{\mathrm{i}}=-\left(1-\phi_{\mathrm{i}}\right)$ ve $\Delta \mathrm{y}_{\mathrm{it}}=\mathrm{y}_{\mathrm{it}}-\mathrm{y}_{\mathrm{it}-1}$ 'dir. Böylece denklem $Y_{i, t}$ 'nin gecikmeli birinci farklarının ilave edildiği genişletilmiş regresyon denklemine dönüşmekte ve tahmin edilmektedir.

CADF istatistik değerleri Pesaran (2007) istatistik değeri ile karşılaştırılmakta, istatistik değerinin tablo değerinden küçük olması durumunda, değişkenin durağan olduğuna karar verilmektedir. Bununla birlikte CADF ile her bir yatay kesite ait değerin durağanlığını tespit etmek güçtür. CADF regresyonu tahmin edildikten sonra $\mathrm{HO}$ hipotezinin geçerliliği panelin geneli için CIPS (Cross-Sectionally Augmented IPS) istatistiği ile test edilebilmektedir. CIPS $=\mathrm{N}^{-1} \sum_{\mathrm{i}=1}^{\mathrm{N}}$ şeklinde ifade edilen CIPS istatistiğinde, gecikmeli değişkenlerin t-istatistiklerinin ortalamaları (CADF) alınmaktadır. CADF testinde CIPS istatistiğinin kullanılmasının temel nedeni, her bir yatay kesite (ülkelere) ait birim kök test istatistiklerinin ortalaması alınarak panelin geneli için birim kök testi yapılabilmesidir (Pesaran, 2007; 267-268).

Serilerin homojenliği ve durağanlığı irdelendikten sonra, elde edilen bilgiler doğrultusunda uygulanacak olan eş-bütünleşme testine karar verilmiştir. Çünkü panel eş-bütünleşme testlerinin varsayımları yapılırken değişkenlerin durağanlık dereceleri, uygulanacak olan testin türünü değiştirmektedir. Bu kapsamda yapılan analizler sonucunda çalışmada, Westerlund tarafından 2008 yılında geliştirilen Durbin-Hausmann Eş-Bütünleşme Testi'nin kullanılması kararlaştırılmıştır (Westerlund, 2007; 209). Ayrıca çalışmada eş-bütünleşme katsayılarının tahmini için Pesaran (2006) tarafından geliştirilen Ortak İlişkili Etkiler (Common Correlated Effect-CCE) tahmin yöntemi kullanılmıştır (Pesaran, 2006; 971).

Serilerin heterojen olmasını ve yatay kesit bağımlılığını göz gönünde bulunduran ve aynı zamanda değişkenlerin durağanlığı hakkında herhangi bir kısıtlama öngörmeyen Durbin- 
Hausmann Eş-Bütünleşme Testi'nde, eşbütünleşmenin varlığı panel ve grup boyutu olmak üzere iki şekilde ele alınmaktadır. Durbin-Hausman panel testinde otoregresif parametrenin, $\mathrm{HO}$ : Eşbütünleşme yoktur ve $\mathrm{H}_{1}$ : Eş-bütünleşme vardır şeklindeki hipotezler altında tüm kesitler için aynı olduğu varsayımı yapılmaktadır. Bu varsayım altında boş hipotezin reddedilmesi, bütün kesitler için eş-bütünleşmenin varlığına işaret etmektedir. Grup testinde ise otoregresif parametrenin kesitler

arasında farklılaşmasına izin verilmektedir. Testte boş hipotezin reddedilmesi, en azından bazı kesitler için eş-bütünleşme ilişkisinin varlığına işaret etmektedir (Bayar vd. 2011;15).

Durbin-Hausmann Testi ile eş-bütünleşme ilişkisinin tespit edilmesi durumunda, değişkenlerin uzun dönem eş-bütünleşme katsayıları tahmin edilebilmektedir. Bu amaçla kullanılan CCE tahmincisi aşağıdaki eşitlik ile ifade edilmektedir.

$$
y_{i t}=\alpha_{i}^{\prime} d_{t}+\beta_{i}^{\prime} x_{i t}+e_{i t} \quad i=1 \ldots . . N, \quad t=1 \ldots . T
$$

(8) nolu $\mathrm{e}_{\mathrm{it}}=\gamma_{\mathrm{i}}^{\prime} \mathrm{f}_{\mathrm{t}}+\varepsilon_{\mathrm{it}}$ eşitlikte şeklindedir. CCE tahmincisi yatay kesit bağımlılığı dikkate almakla birlikte araştırmacılara her bir kesit için ayrı ayrı sonuçlar verebilmektedir. Yapılan analizler sonucunda serilerin homojen olduğuna ve yatay kesit bağımlılığın var olduğuna karar verilmişse, bu durumda Yatay Kesit Bağımlılığı Altında Ortalama Grup Etkileri (Common Correlated Mean Group Effects-CCMGE) tahmincisi kullanılmaktadır. Ortak etkiler, sabit veya gözlenemeyen ortak etkiler hakkında çok az bilgi var ise Havuzlanmış Ortak İlişkiler (Common Correlated Effects Pooled-CCEP) tahmincisi kullanılmaktadır (Pesaran, 2006; 982).
Son olarak, bu çalışmada yapılan panel veri analizlerinde Gauss 10 yazılım programı ve Eviews 8 ekonometrik analiz paket programı kullanılmıştır.

\section{ANALIZ BULGULARI}

OGT göstergesi olan gelir yakınsaması ya da ıraksamasının tespit edilmesi amacıyla çalışmada, sırasıyla en küçük kareler tahmin yöntemine dayalı mutlak $\beta$ yakınsaması ve birim kök testleriyle yakınsama analizleri gerçekleştirilmiştir. Analiz sonuçları Tablo 1 ve Tablo 2'de sunulmuştur.

Tablo 1: Mutlak $\beta$ Yakınsaması Modeli Tahmin Sonuçları

\begin{tabular}{|c|c|c|c|c|}
\hline Değişken & Katsayı & Standart Hata & t- Statistiği & p Değeri \\
\hline$C$ & 0.189 & 0.022 & 8.627 & 0.000 \\
\hline$X$ & -0.021 & 0.003 & -7.623 & 0.000 \\
\hline \multicolumn{2}{|l|}{$\mathbf{R}^{2} 0.691$} & Düzeltilmiş $\mathbf{R}^{2:} 0.679$ & F-değeri: $58.216 \quad$ Prob (F): $0.000 \quad$ DW: 2.039 \\
\hline
\end{tabular}

Tabloda $X$ ile gösterilen $\beta$ katsayısının işaretinin negatif yönlü olduğu görülmektedir. Bu değişkene ait katsayı istatistiki açıdan \% 1 önem düzeyinde anlamlıdır ve bir bütün olarak modelin \%1 önem düzeyinde anlamlı olduğu söylenebilir. R2 değeri modelin açıklama gücünün yüksek olduğunu işaret etmektedir. Mutlak $\beta$ yakınsaması sonuçlarına göre, $\beta$ katsayısı (-0.021)'dir. Koşulsuz yakınsama katsayısı olan katsayı değerinin $\beta<0$ olması, mutlak yakınsamanın varlığını işaret etmektedir. Buna göre ele alınan 28 ülkede gelir yakınsamasının söz konusu olduğunu söylemek mümkündür. Bu sonuç ülkelerde başlangıçta daha düşük olan gelir düzeyinin, büyümeyi artıracağına işaret etmektedir.

Tablo 1'de verilen ve ele alınan tüm ülkeler için belirlenen yakınsama katsayısı, ülke özelinde yüksek gelirli ülkelere yakınsama olup olmadığı sorusunu gündeme getirmektedir. Buna göre tahmin sonuçları Tablo 2'deki gibidir. 
Tablo 2: Birim Kök Testine Dayalı Yakınsama Analizi Sonuçları

\begin{tabular}{|c|c|c|c|}
\hline Ülke & İstatistik & G.D. (*) $^{*}$ & Karar \\
\hline ARJ & $-3.818^{(\mathrm{c})}$ & 2 & Yakınsama \\
\hline BEL & -2.665 & 2 & Iraksama \\
\hline BOT & $-3.530^{(c)}$ & 2 & Yakınsama \\
\hline BRE & -3.276 & 2 & Iraksama \\
\hline CEZ & -2.531 & 2 & Iraksama \\
\hline CIN & $-3.625^{(c)}$ & 2 & Yakınsama \\
\hline DOC & $-3.779^{(c)}$ & 3 & Yakınsama \\
\hline EKV & $-4.621^{(b)}$ & 2 & Yakınsama \\
\hline GAB & -2.505 & 2 & Iraksama \\
\hline GRE & $-3.724^{(c)}$ & 2 & Yakınsama \\
\hline GAF & -3.448 & 2 & Iraksama \\
\hline IRA & -3.295 & 2 & Iraksama \\
\hline JAM & -2.154 & 2 & Iraksama \\
\hline KOL & -2.625 & 2 & Iraksama \\
\hline KOS & $-5.774^{(a)}$ & 2 & Yakınsama \\
\hline MAC & -2.520 & 2 & Iraksama \\
\hline MAL & $-3.681^{(c)}$ & 2 & Yakınsama \\
\hline MAU & $-3.913^{(b)}$ & 3 & Yakınsama \\
\hline MEK & $-3.569^{(c)}$ & 2 & Yakınsama \\
\hline PAN & $-3.974^{(b)}$ & 2. & Yakınsama \\
\hline PER & -3.174 & 3 & Iraksama \\
\hline STL & $-4.913^{(a)}$ & 2 & Yakınsama \\
\hline SVG & $-3.975^{(b)}$ & 2 & Yakınsama \\
\hline TAY & -2.414 & 2 & Iraksama \\
\hline TUN & -2.718 & 2 & Iraksama \\
\hline TUR & $-4.934^{(a)}$ & 2 & Yakınsama \\
\hline URD & -2.328 & 2 & Iraksama \\
\hline VEN & $-6.793^{(a)}$ & 2 & Yakınsama \\
\hline \multicolumn{4}{|c|}{ CIPS: $(-3.571)^{(a)}$} \\
\hline \multicolumn{2}{|c|}{ CADF K.D. ${ }^{(* *)}$} & \multicolumn{2}{|c|}{ CIPS K.D..$^{(* *)}$} \\
\hline$\% 1$ & $(-4.69)$ & $\% 1$ & $(-2.81)$ \\
\hline$\% 5$ & $(-3.88)$ & $\% 5$ & $(-2.66)$ \\
\hline$\% 10$ & $(-3.49)$ & $\% 10$ & $(-2.58)$ \\
\hline
\end{tabular}

${ }^{(*)}$ G.D. gecikme uzunluğunu göstermektedir.

${ }^{(* *)}$ K.D.: CADF ve CIPS istatistiği kritik değerleri, Pesaran (2007)

Tablo 1c, 276 ve Tablo 2c 281'den alınmıştır.
Tablo 2'ye göre Arjantin, Botsvana, Çin, Dominik Cumhuriyeti, Ekvator, Greneda, Kosta Rika, Malezya, Mauritius, Meksika, Panama, Saint Lucia, Saint VincentGrenadinler, Türkiye ve Venezuela için test istatistikleri $\% 1, \% 5$ ve $\% 10$ önem düzeylerinde anlamlıdır. Buna göre söz konusu ülkelerde gelir serileri durağanlık göstermektedir. Dolayısıyla bu ülkelerin yüksek gelirli ülkelerle yakınsama halinde olduklarını söylemek mümkündür. Söz konusu bulgu yukarıda belirtilen 15 üst orta gelirli ülkenin, yüksek gelirli ülkelere yakınsadığının ve dolayısıyla bu ülkelerin OGT'ye düşmeyebileceklerinin göstergesi olarak kabul edilebilir. Öte yandan Belize, Brezilya, Cezayir, Gabon, Güney Afrika, İran, Jamaika, Kolombiya, Macaristan, Peru, Tayland, Tunus ve Ürdün'de ise gelir serilerinin durağan olmadıkları ve bu ülkelerin yüksek gelirli ülkelerden ıraksadıkları görülmektedir. Buna göre söz konusu 13 üst orta gelirli ülkenin OGT'ye düşebileceklerini söylemek mümkündür.

Çalışmada üst orta gelirli ülkelerin OGT'ye düşüp düşmediklerini, düşmüşler ise OGT'den kurtulmayı sağlayacak olan değişkelerin neler olduğunu (OGT'nin belirleyicilerini) tespit etmek amacıyla panel veri analizleri yapılmıştır. İlk olarak homojenlik ve yatay kesit bağımlılık testleri yapılmıştır. Söz konusu testlere ilişkin bulgular Tablo 3, Tablo 4 ve Tablo 5'deki gibidir.

Tablo 3: Homojenlik (Delta) Testi Sonuçları

\begin{tabular}{|l|c|c|}
\hline Test & Test İstatistiği & p Değerleri \\
\hline Delta_tilde & 22.138 & 0.000 \\
\hline Delta_tilde_adj & 26.699 & 0.000 \\
\hline
\end{tabular}

Tablo 3 panel veri modellerindeki $\beta$ eğim katsayılarının yatay kesitler arasında farklı olup olmadığı test eden Delta Testi kullanılarak yapılan analizler sonucunda elde edilen bulguları göstermektedir. Analiz sonuçlarına göre hesaplanan olasılık değerleri \% 1 önem düzeyinde anlamlıdırlar. $\mathrm{Bu}$ durumda $\mathrm{H}_{0}$ şeklindeki temel hipotez reddedilmektedir. Buna göre eğim katsayılarının heterojen olduğunu söylemek mümkündür. Böylece her kesit için yapılacak eş-bütünleşme testinin geçerli ve güvenilir olduğu tespit edilmiş olmaktadır.

Tablo 4 çalışmada ele alınan her bir değişken için; Tablo 5 ise modelin geneli için yapılan yatay kesit bağımlılık testlerinin sonuçlarını göstermektedirler. 
Tablo 4: Değişken Düzeyinde Yatay Kesit Bağımlılığı Test Sonuçları

\begin{tabular}{|c|c|c|c|c|c|c|c|c|c|}
\hline & $\mathbf{Y}$ & BAG & ENF & ILK & SER & OPN & OZG & TAS & TLF \\
\hline Sabitli & $\begin{array}{l}\text { İstatistik } \\
\text { (p) }\end{array}$ & (p) & $\begin{array}{l}\text { İstatistik } \\
\text { (p) }\end{array}$ & $\begin{array}{l}\text { İstatistik } \\
(p)\end{array}$ & $\begin{array}{l}\text { İstatistik } \\
\text { (p) }\end{array}$ & $\begin{array}{l}\text { İstatistik } \\
(p)\end{array}$ & (p) & $\begin{array}{l}\text { İstatistik } \\
(p)\end{array}$ & $\begin{array}{l}\text { İstatistik } \\
\text { (p) }\end{array}$ \\
\hline$C D_{L M 1}$ & $\begin{array}{c}507.828 \\
(0.000) \\
\end{array}$ & $\begin{array}{c}495.275 \\
(0.000) \\
\end{array}$ & $\begin{array}{c}608.583 \\
(0.000) \\
\end{array}$ & $\begin{array}{c}434.869 \\
(0.023) \\
\end{array}$ & $\begin{array}{c}507.990 \\
(0.000) \\
\end{array}$ & & & & $\begin{array}{r}489 . \\
(0.0 \\
\end{array}$ \\
\hline$C D_{L M}$ & $(0.001)$ & $\begin{array}{l}-3.082 \\
(0.001) \\
\end{array}$ & $\begin{array}{c}6.654 \\
(0.000) \\
\end{array}$ & $\begin{array}{l}-2.421 \\
(0.008) \\
\end{array}$ & $\begin{array}{l}-1.873 \\
(0.031) \\
\end{array}$ & & & & \\
\hline $\mathrm{CD}_{\mathrm{LM2}}$ & $\begin{array}{r}4.72 \\
(0.00 \\
\end{array}$ & $\begin{array}{r}4 \\
(0 . \\
\end{array}$ & $\begin{array}{c}8.386 \\
(0.000) \\
\end{array}$ & $\begin{array}{c}2.068 \\
(0.019) \\
\end{array}$ & $\begin{array}{c}4.728 \\
(0.000) \\
\end{array}$ & & & & \\
\hline \multirow[t]{2}{*}{$\mathrm{CD}_{\text {LMadj }}$} & $\begin{array}{l}-0.12 \\
(0.55\end{array}$ & 1. & $\begin{array}{l}-1.7 \\
(0.9 \\
\end{array}$ & $\begin{array}{c}4.378 \\
(1.000)\end{array}$ & $\begin{array}{l}.780 \\
.000) \\
\end{array}$ & & & $\begin{array}{c}3.384 \\
(0.000)\end{array}$ & $\begin{array}{c}6.084 \\
(0.000) \\
\end{array}$ \\
\hline & $\mathbf{Y}$ & BAG & ENF & ILK & SER & OPN & . & TAS & TLF \\
\hline $\begin{array}{l}\text { Sabitli// } \\
\text { Trendli }\end{array}$ & $\begin{array}{l}\text { İstatistik } \\
(p)\end{array}$ & $\begin{array}{c}\text { İstatistik } \\
(p)\end{array}$ & $\begin{array}{l}\text { İstatistik } \\
(p)\end{array}$ & $\begin{array}{l}\text { İstatistik } \\
(p)\end{array}$ & $\begin{array}{l}\text { İstatistik } \\
(p)\end{array}$ & $\begin{array}{l}\text { İstatistik } \\
(p)\end{array}$ & $\begin{array}{l}\text { İstatistik } \\
(p)\end{array}$ & $\begin{array}{l}\text { İstatistik } \\
(p)\end{array}$ & $\begin{array}{l}\text { İstatistik } \\
(p)\end{array}$ \\
\hline $\mathrm{CD}_{\mathrm{LM1}}$ & $\begin{array}{c}495.983 \\
(0.000)\end{array}$ & $\begin{array}{c}525.086 \\
(0.000)\end{array}$ & $\begin{array}{c}625.120 \\
(0.000)\end{array}$ & $\begin{array}{c}449.319 \\
(0.007)\end{array}$ & $\begin{array}{c}517.206 \\
(0.000)\end{array}$ & $\begin{array}{c}490.314 \\
(0.000)\end{array}$ & $\begin{array}{c}645.108 \\
(0.000)\end{array}$ & $\begin{array}{c}532.167 \\
(0.000)\end{array}$ & $\begin{array}{c}561.349 \\
(0.000)\end{array}$ \\
\hline $\mathrm{CD}_{\mathrm{LM}}$ & $\begin{array}{c}-2.545 \\
(0.005) \\
\end{array}$ & $\begin{array}{l}-3.022 \\
(0.001) \\
\end{array}$ & $\begin{array}{c}6.690 \\
(0.000) \\
\end{array}$ & $\begin{array}{c}-2.214 \\
(0.013) \\
\end{array}$ & $\begin{array}{c}-2.035 \\
(0.021) \\
\end{array}$ & & $\begin{array}{l}-2.860 \\
(0.002) \\
\end{array}$ & $\begin{array}{l}-2.775 \\
(0.000) \\
\end{array}$ & $\begin{array}{l}-3.040 \\
(0.001) \\
\end{array}$ \\
\hline $\mathrm{CD}_{\mathrm{LM2}}$ & $\begin{array}{c}4.291 \\
(0.000) \\
\end{array}$ & $\begin{array}{c}5.349 \\
(0.000)\end{array}$ & $\begin{array}{c}8.988 \\
(0.000) \\
\end{array}$ & $\begin{array}{c}2.594 \\
(0.005) \\
\end{array}$ & $\begin{array}{c}5.063 \\
(0.000) \\
\end{array}$ & $\begin{array}{c}4.085 \\
(0.000) \\
\end{array}$ & $\begin{array}{c}9.715 \\
(0.000) \\
\end{array}$ & $\begin{array}{c}5.607 \\
(0.000) \\
\end{array}$ & $\begin{array}{c}6.668 \\
(0.000) \\
\end{array}$ \\
\hline $\mathrm{CD}_{\text {LMadj }}$ & $\begin{array}{c}0.336 \\
(0.368)\end{array}$ & $\begin{array}{c}1.577 \\
(0.057)\end{array}$ & $\begin{array}{l}-1.665 \\
(0.952)\end{array}$ & $\begin{array}{l}-4.203 \\
(1.000)\end{array}$ & $\begin{array}{c}4.574 \\
(0.000)\end{array}$ & $\begin{array}{c}2.800 \\
(0.003)\end{array}$ & $\begin{array}{l}-3.021 \\
(0.999)\end{array}$ & $\begin{array}{c}3.248 \\
(0.001)\end{array}$ & $\begin{array}{c}6.322 \\
(0.000)\end{array}$ \\
\hline
\end{tabular}

Tablo 4'de görüldüğü gibi $\mathrm{T}>\mathrm{N}$ durumuna uyan $C D_{L M 1}$ ile $\mathrm{N}>\mathrm{T}$ ve $\mathrm{T}=\mathrm{N}$ durumlarına uyan $C D_{L M}$ ve $\mathrm{CD}_{\mathrm{LM} 2}$ testleri sonucunda, birimler arasında yatay kesit bağımlılığın olmadığını ileri süren $\mathrm{H}_{0}$ hipotezi $\% 1$ ve \% 5 önem düzeylerinde hem sabitli hem de sabitlitrendli modelde reddedilmiştir. Test sonuçlarından hareketle, birimler arasında yatay kesit bağımlılığın var olduğu kabul edilmiştir. Bununla birlikte, $\mathrm{T}>\mathrm{N}$ durumuyla uyumlu olan $\mathrm{CD}_{\mathrm{LMadj}}$ testinin sonuçları yatay kesit bağımsızlığını öngören boş hipotezin bazı değişkenler için kabul edilmesini, bazı değişkenler için reddedilmesini öngörmektedir. Örneğin; Y, BAG, ENF, ILK ve OZG değişkenleri için hem sabitli hem de sabitlitrendli modellerde olasılık değeri \% 5'ten büyüktür ve bu nedenle $\mathrm{H}_{0}$ hipotezi kabul edilmektedir. SER, OPN, TAS ve TLF değişkenleri için ise $\% 1$ önem düzeyinde $\mathrm{H}_{0}$ hipotezi reddedilmektedir.

$C D_{\text {LMadj }}$ testi sonucunda, değişkenlerin bazıları arasında yatay kesit bağımlılık olması, bazıları arasında ise olmaması, modelin genelinde yatay kesit bağımlıık probleminin olup olmadığı sorusunu akla getirmiştir. Modelde yatay kesit bağımlılığı araştıran test sonuçları Tablo 5'te sunulmuştur.
Tablo 5: Model Düzeyinde Yatay Kesit Bağımlılığı Test Sonuçları

\begin{tabular}{|l|c|c|}
\hline Test & Statistik & p Değerleri \\
\hline CD $_{\text {LM1 }}$ & 640.437 & 0.000 \\
\hline CD $_{\text {LM }}$ & 11.052 & 0.000 \\
\hline CD $_{\text {LM2 }}$ & 9.545 & 0.000 \\
\hline CD $_{\text {LMadj }}$ & 9.335 & 0.000 \\
\hline
\end{tabular}

Tablo 5'de görüldüğü gibi $\mathrm{CD}_{\mathrm{LM}^{\prime}} \mathrm{CD}_{\mathrm{LM}^{\prime}} \mathrm{CDL}_{\mathrm{M} 2}$ ve $\mathrm{CD}_{\text {LMadj }}$ testleri sonucunda, birimler arasında yatay kesit bağımlıı̆̆ın olmadığını ileri süren $\mathrm{H}_{0}$ hipotezi \% 1 önem düzeyinde reddedilmiştir. Test sonuçlarından hareketle, birimler arasında yatay kesit bağımlıı̆̆ın var olduğu kabul edilmiştir. Buna göre ülke grupları itibariyle paneli oluşturan kesitler arasında yatay kesit bağımlılık bulunduğu için ülkelerden birinde meydana gelen beklenmeyen bir olay diğerlerini etkileyebilmektedir.

Yatay kesit bağımlılığı dikkate alan ve II. nesil birim kök testleri olarak adlandırılan tahminciler içerisinde yer alan Pesaran'ın CADF-CIPS birim kök testine ait sonuçlar Tablo 6'da verilmiştir. 


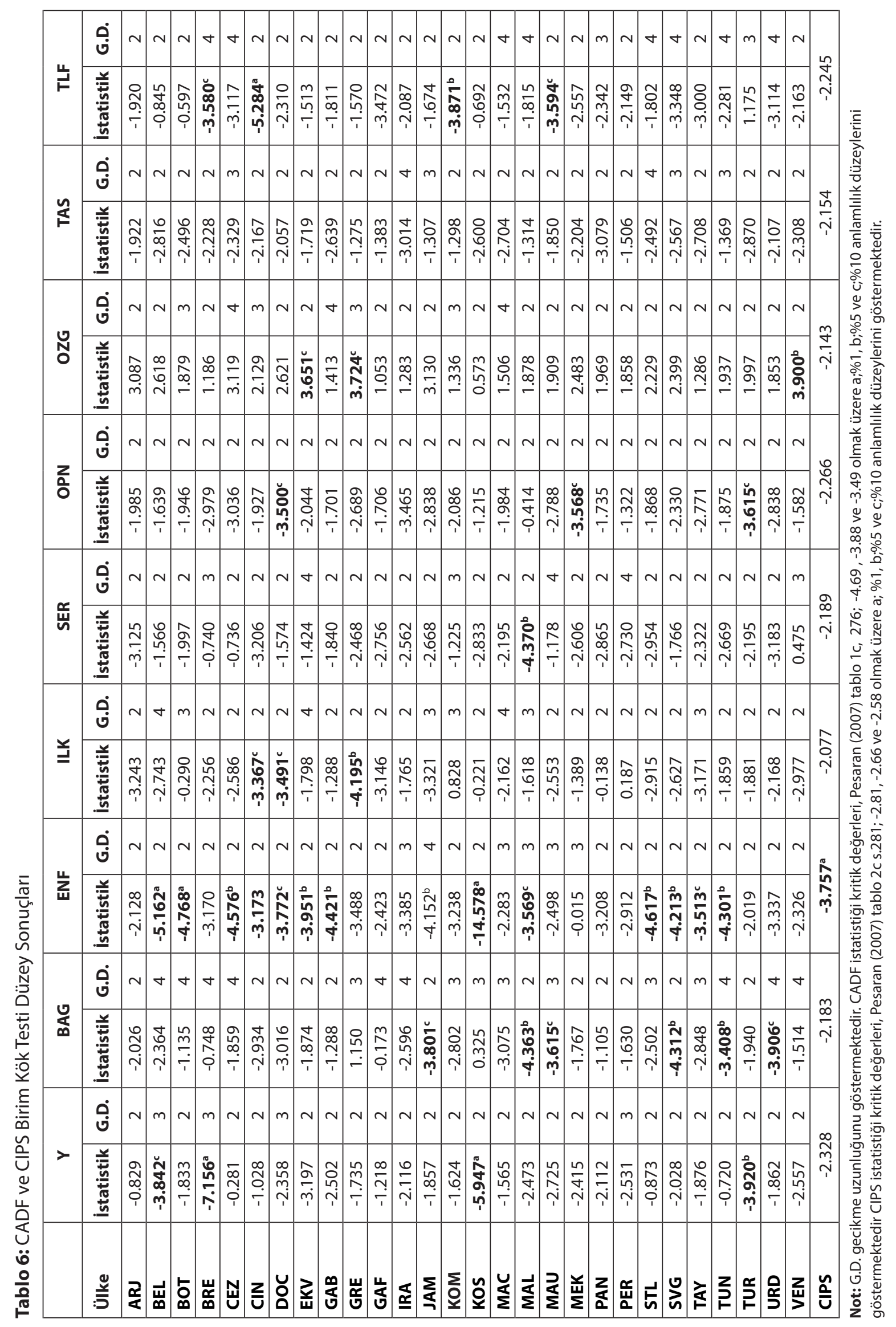


峞 $\overline{\frac{\varepsilon}{0}}$

ᄃ है

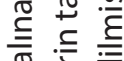

Q $\frac{\sigma}{2}$ व

व

중 检

है

产 $\frac{\bar{v}}{\bar{v}}$

$=$ 醇

这 $\frac{\text { Un }}{\frac{\pi}{2}}$

总 ฮั

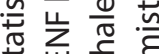

는

«

营

ᄃ 중

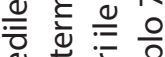

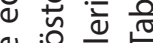

응 은

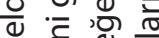

중ㅎㅁㅇ

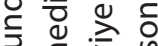

एह ऐे

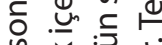

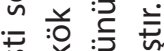

$\leftarrow$ ह है ह

㟧

वे.

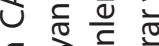

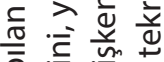

믐 河语

入흥

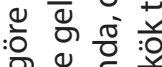

의

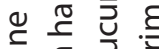

든

늄 융

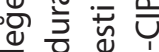

入े으웡

:긍 $\underline{=}$ ह

乐高 离

읻

商 号

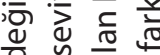

웜등

迹

: N 文这

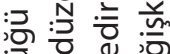

:을 ह 항

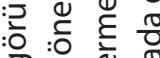

ठ - 仓

중 울 는

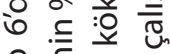

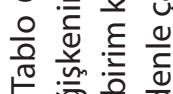

谞

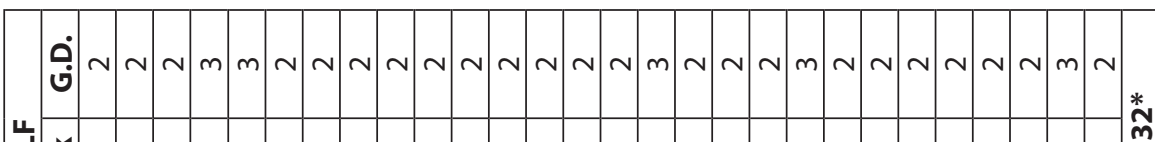

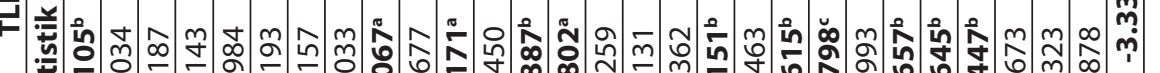
ڤै

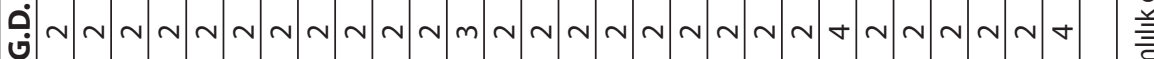

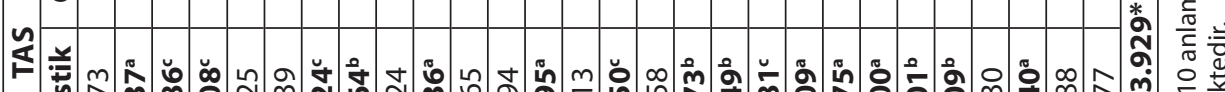
=

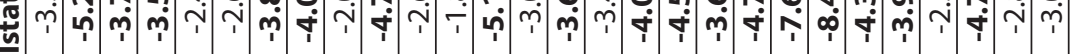

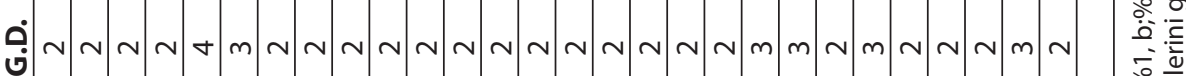

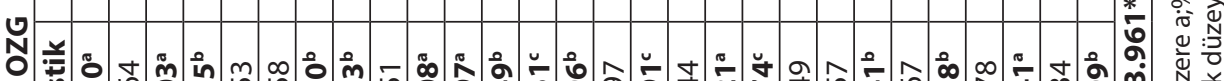

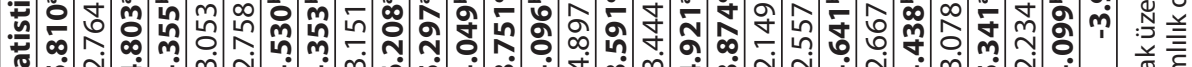
ڤ్

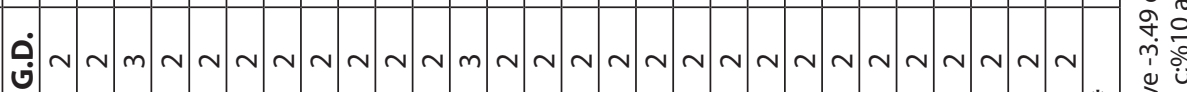

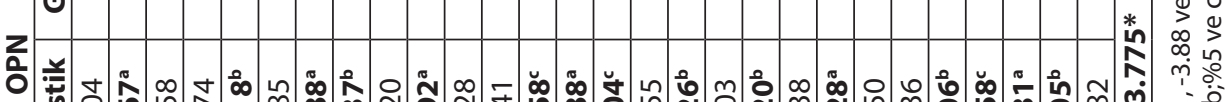

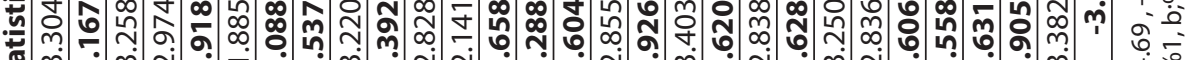

†ึ

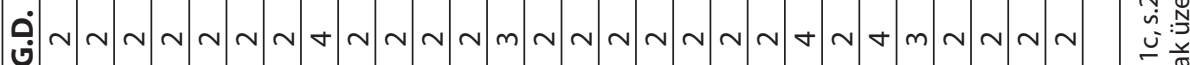

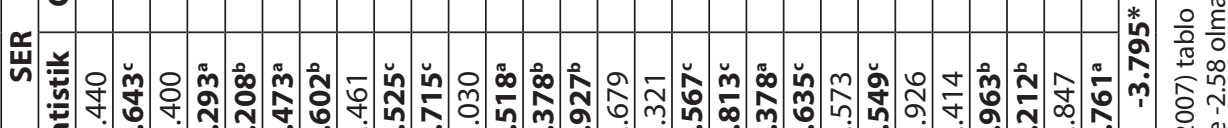

E

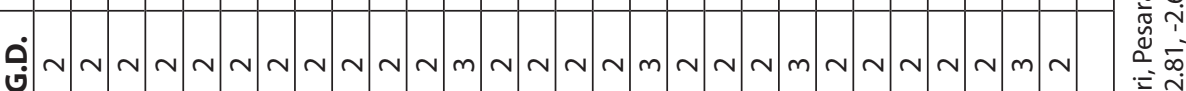

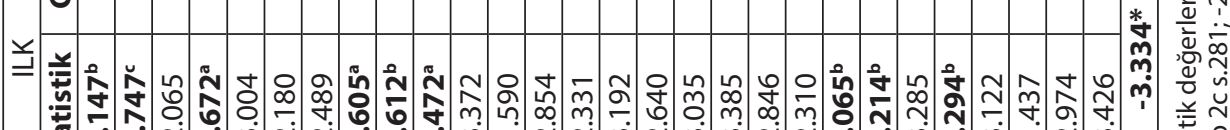

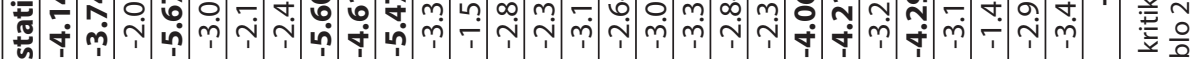

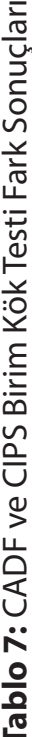

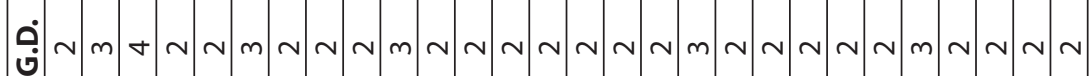

汤要

芒合

营

象

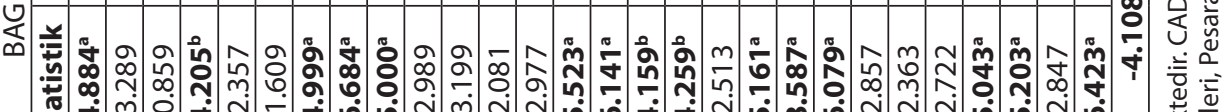

E

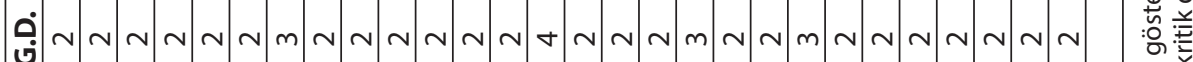

-

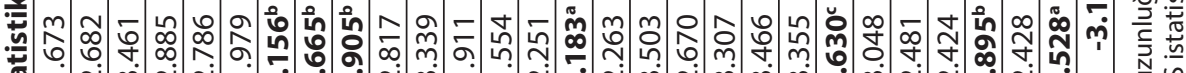

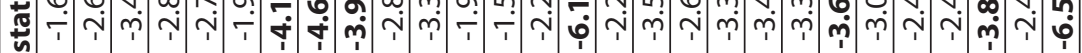
$\underline{\underline{n}}$

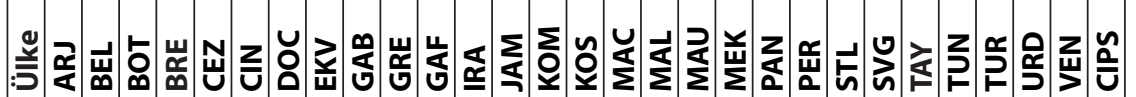


Tablo 7'de yer alan CADF-CIPS birim kök testi sonuçlarına göre, 1982-2012 dönemi için çalışmada ele alınan tüm değişkenlerin birinci fark değerleri ile [I(1)] durağan hale geldikleri, yani birim kök içermedikleri tespit edilmiştir.

Çalışmada kullanılan Durbin-Hausmann EşBütünleşme Testi, serilerin heterojen olmasını ve yatay kesit bağımlılıklarını göz gönünde bulundurmakta ve aynı zamanda değişkenlerin durağanlığı hakkında herhangi bir kısıtlama öngörmemektedir. Eşbütünleşmenin varlığını panel ve grup boyutu olmak üzere iki şekilde ele alan Durbin-Hausmann EşBütünleşme Testi'nin sonuçları Tablo 8'de verilmiştir.

Tablo 8: Westerlund (2008) Durbin-Hausmann Test Sonuçları

\begin{tabular}{|l|c|c|}
\hline Test & Test İstatistiği & p Değerleri \\
\hline dh_g & 2.376 & 0.031 \\
\hline dh_p & 2.150 & 0.044 \\
\hline
\end{tabular}

Eş-Bütünleşme testi sonuçlarına göre, otoregresif parametrenin tüm kesitler için aynı olduğu varsayımı altında hem grup hem de panel istatistikleri \% 5 önem düzeyinde anlamlıdırlar. Buna göre eş-bütünleşme yoktur şeklindeki $H_{0}$ hipotezi reddedilmektedir. Boş hipotezin reddedilmesi, panelde yer alan bütün kesitler için eş-bütünleşmenin var olduğunu göstermektedir. Bu durum 28 üst orta gelirli ülkede GSYiH ile çalışmada ele alınan 8 bağımsız değişken arasında uzun dönemli bir ilişki olduğunu göstermektedir.

Yapılan Durbin-Hausmann Testi, eş-bütünleşme ilişkisinin var olduğunu göstermiştir. Bu nedenle çalışmada değişkenlerin uzun dönem eş-bütünleşme katsayıları tahmin edilmiştir. Tablo 9 CCE tahmincisinin yatay kesit birimler için hesaplanan regresyon katsayılarını göstermektedir. 
屴

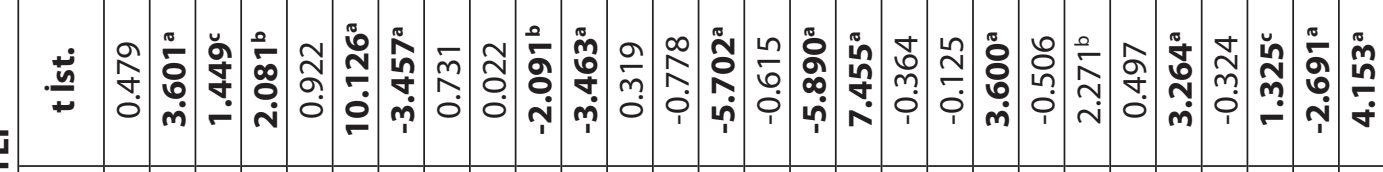

ทุ

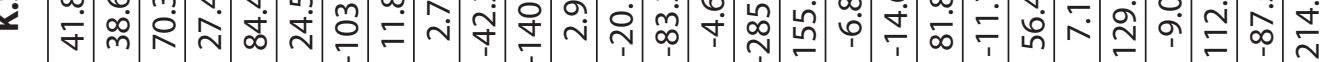

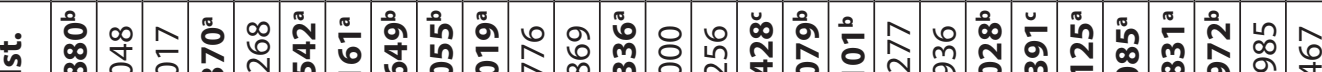

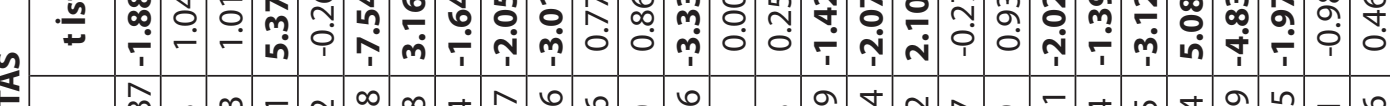

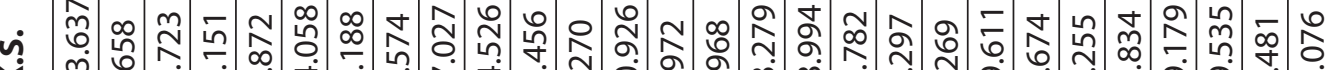
守茓

..艹 Y

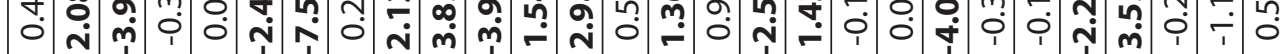
O

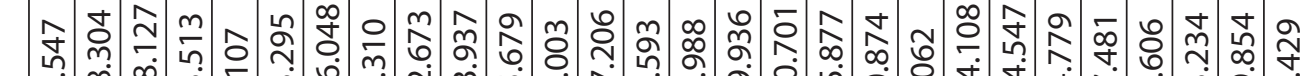

ทุ

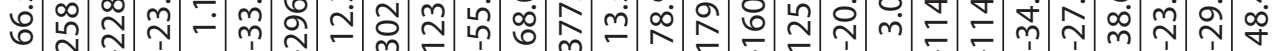

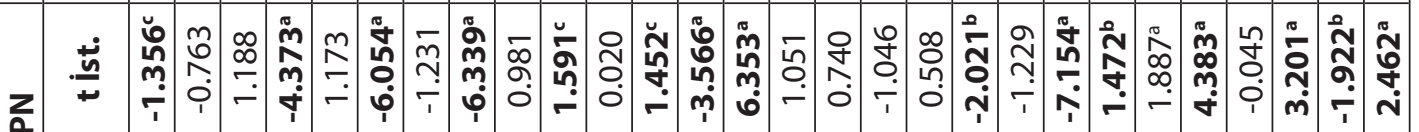

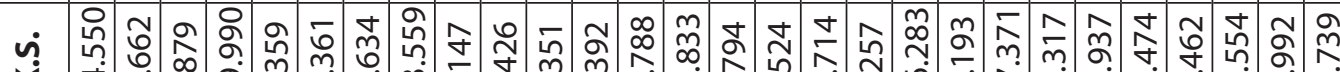

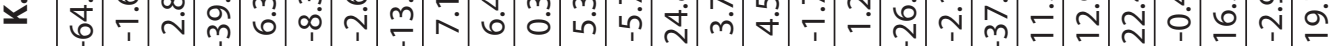

\begin{tabular}{|c|c|c|c|c|c|c|c|c|c|c|c|c|c|c|c|c|c|c|c|c|c|c|c|c|c|c|c|c|}
\hline & $\frac{\ddot{n}}{t}$ & $\begin{array}{c}\stackrel{0}{0} \\
m \\
m \\
m \\
m\end{array}$ & 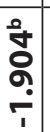 & 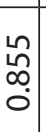 & $\begin{array}{l}0 \\
\infty \\
0 \\
\dot{0} \\
\end{array}$ & 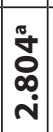 & 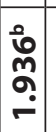 & $\begin{array}{l}\text { Ñ } \\
\text { గ̂: } \\
\text { ஸे }\end{array}$ & $\begin{array}{l}\infty \\
\infty \\
\sigma \\
- \\
-\end{array}$ & $\frac{R}{r}$ & 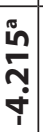 & 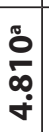 & $\begin{array}{l}\infty \\
m \\
m \\
n \\
m \\
1\end{array}$ & & $\begin{array}{l}0 \\
0 \\
0 \\
1 \\
1\end{array}$ & $\begin{array}{l}0 \\
\frac{n}{n} \\
i\end{array}$ & $\begin{array}{l}\bar{m} \\
\tilde{a} \\
\grave{i}\end{array}$ & $\underset{i}{\stackrel{m}{i}}$ & '. & 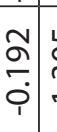 & 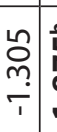 & 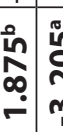 & 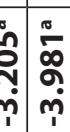 & 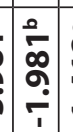 & 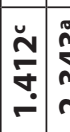 & 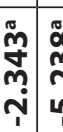 & 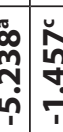 & \\
\hline & ทุ & & $\begin{array}{l}\frac{T}{N} \\
m \\
\frac{1}{1}\end{array}$ & 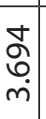 & $\begin{array}{l}\infty \\
0 \\
m \\
m \\
m\end{array}$ & & $\frac{N}{\sigma}$ & $\begin{array}{l}\widetilde{Z} \\
\widehat{\alpha} \\
\infty\end{array}$ & $\begin{array}{l}a \\
\hat{m} \\
\end{array}$ & 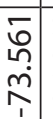 & 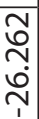 & $\begin{array}{l}\hat{0} \\
\hat{0} \\
\sigma \\
\sigma\end{array}$ & 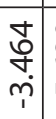 & 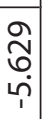 & 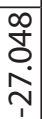 & $\frac{\bar{\tau}}{\bar{\tau}}$ & 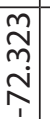 & $\begin{array}{l}\bar{\sigma} \\
\infty \\
\stackrel{T}{1}\end{array}$ & ช্ & 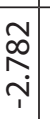 & 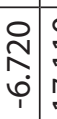 & & 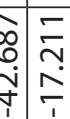 & 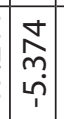 & 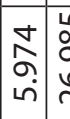 & 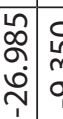 & & \\
\hline \multirow{2}{*}{ 兰 } & 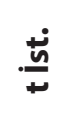 & 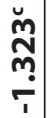 & \begin{tabular}{l}
\multicolumn{1}{c}{} \\
$\hat{g}$ \\
0 \\
0 \\
1
\end{tabular} & $\begin{array}{l}\tilde{n} \\
\hat{\alpha} \\
\dot{+}\end{array}$ & 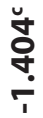 & ○. & 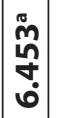 & $\begin{array}{l}\stackrel{n}{0} \\
\hat{o} \\
0 \\
m \\
m\end{array}$ & 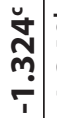 & $\begin{array}{c}\stackrel{0}{0} \\
\text { m. } \\
\end{array}$ & 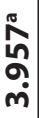 & $\begin{array}{l}\text { t } \\
\infty \\
\dot{0} \\
1\end{array}$ & 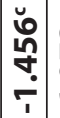 & $\begin{array}{l}\tilde{n} \\
\stackrel{n}{\sigma} \\
0 \\
0\end{array}$ & 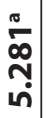 & $\dot{\sim}$ & $\begin{array}{l}0 \\
0 \\
\\
\end{array}$ & i & & \begin{tabular}{c} 
\pm \\
\\
\hdashline
\end{tabular} & 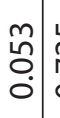 & & & 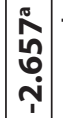 & 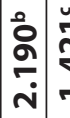 & 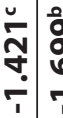 & & \\
\hline & जู่ & (c) & \begin{tabular}{l}
$\bar{\emptyset}$ \\
\multirow{1}{n}{} \\
$\hat{\varphi}$ \\
1
\end{tabular} & 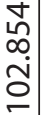 & 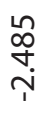 & $\infty$ & $\begin{array}{l}0 \\
\vdots \\
\sigma \\
0\end{array}$ & $\begin{array}{l}0 \\
0 \\
0 \\
0\end{array}$ & 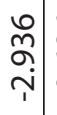 & $\begin{array}{l}\circ \\
0 \\
0 \\
\sigma \\
\sigma\end{array}$ & 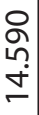 & $\begin{array}{c}\bar{\sigma} \\
\overline{0} \\
\dot{p}\end{array}$ & $\mid$\begin{tabular}{l}
0 \\
$\tilde{n}$ \\
6 \\
$\dot{0}$ \\
\hdashline \\
\end{tabular} & $\begin{array}{l}0 \\
\text { oे } \\
\text { ?. } \\
0 \\
0\end{array}$ & 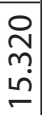 & 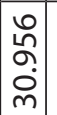 & 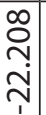 & $\begin{array}{l}\infty \\
0 \\
\vdots \\
\dot{n}\end{array}$ & 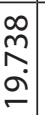 & $\begin{array}{l}\stackrel{d}{\mathbb{N}} \\
\stackrel{0}{0} \\
\end{array}$ & 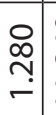 & & & $\stackrel{\operatorname{Ln}}{n}$ & \begin{tabular}{|c|c} 
\\
$m$ \\
$\dot{m}$ \\
\end{tabular} & 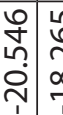 & & \\
\hline \multirow{2}{*}{ 岂 } & \pm & 守 & $\frac{\bar{m}}{\frac{m}{\sigma}}$ & $\frac{0}{0}$ & 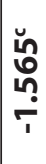 & ָ̀ & 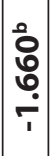 & $\begin{array}{l}\text { ŏg } \\
\hat{n} \\
\\
\end{array}$ & 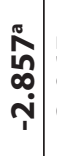 & $\begin{array}{l}\hat{n} \\
0 \\
0 \\
\\
\end{array}$ & $\begin{array}{l}0 \\
0 \\
0 \\
\\
\end{array}$ & 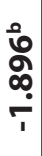 & 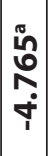 & 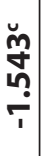 & $\begin{array}{l}\text { مू } \\
\text { m. } \\
0 \\
\end{array}$ & 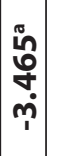 & $\begin{array}{l}\frac{0}{0} \\
\frac{0}{0} \\
\dot{7}\end{array}$ & 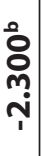 & 芦 & ب̆. & $\begin{array}{l}\text { ळ్ } \\
\text { ô }\end{array}$ & & 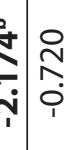 & 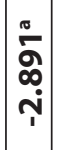 & 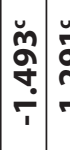 & 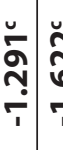 & & \\
\hline & जู่ & $\begin{array}{l}\bar{N} \\
\bar{i}\end{array}$ & $\begin{array}{l}\infty \\
m \\
\frac{m}{T}\end{array}$ & $\begin{array}{l}m \\
0 \\
0 \\
0\end{array}$ & $\begin{array}{l}\tilde{N} \\
0 \\
0 \\
0 \\
\end{array}$ & & 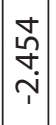 & $\begin{array}{l}\frac{\nabla}{0} \\
0 \\
\vdots \\
1\end{array}$ & 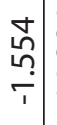 & $\frac{+}{\top}$ & 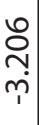 & 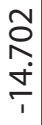 & $\begin{array}{l}\tilde{J} \\
\dot{\gamma} \\
\dot{\gamma}\end{array}$ & $\begin{array}{l}\hat{0} \\
0 \\
\dot{\varphi}\end{array}$ & $\begin{array}{l}\grave{\partial} \\
\dot{0} \\
\dot{\varphi}\end{array}$ & $\mid \begin{array}{l}\bar{\sigma} \\
\substack{n \\
+} \\
1\end{array}$ & 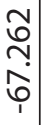 & 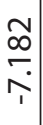 & q & $\begin{array}{c}m \\
\stackrel{n}{2} \\
\frac{1}{1}\end{array}$ & $\begin{array}{l}\infty \\
\infty \\
\\
\end{array}$ & & 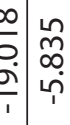 & $\mid \begin{array}{c}0 \\
\stackrel{m}{m} \\
\stackrel{p}{p}\end{array}$ & 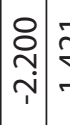 & 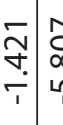 & & \\
\hline \multirow[b]{2}{*}{$\infty$} & & \begin{tabular}{l} 
fo \\
\hdashline \\
\end{tabular} & - & 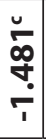 & 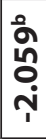 & $\begin{array}{l}\text { no } \\
0 \\
i \\
\end{array}$ & 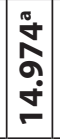 & 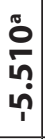 & $\begin{array}{c}\tilde{\sigma} \\
\bar{\sigma} \\
\dot{p} \\
1\end{array}$ & $\frac{\dot{J}}{\dot{m}}$ & $\begin{array}{l}\grave{N} \\
\stackrel{0}{0}\end{array}$ & $\frac{n}{n}$ & 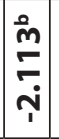 & $\begin{array}{l}\tilde{\sigma} \\
\bar{q} \\
\\
1\end{array}$ & 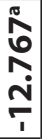 & $\begin{array}{l}\infty \\
0 \\
0\end{array}$ & $\stackrel{+}{\stackrel{+}{-}}$ & 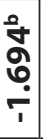 & "i' & 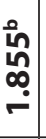 & $\underset{\Xi}{\stackrel{\Xi}{\sigma}}$ & & 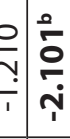 & $\begin{array}{l}n \\
\alpha \\
\vdots \\
0\end{array}$ & \begin{tabular}{|l|l|}
0 & \multicolumn{1}{|c|}{} \\
0 & 8 \\
& 8 \\
\end{tabular} & 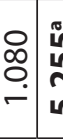 & 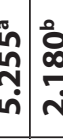 & \\
\hline & $v$ & 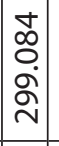 & $\stackrel{\infty}{\curvearrowright}$ & s & \& & in & $\begin{array}{l}0 \\
\tilde{n} \\
\tilde{j} \\
\tilde{n}\end{array}$ & $\left|\begin{array}{l}0 \\
0 \\
0\end{array}\right|$ & $\begin{array}{l}0 \\
\hat{n} \\
0 \\
p \\
1\end{array}$ & రి & $\stackrel{\infty}{\sim}$ & $\underset{\sim}{\overleftarrow{\sim}}$ & 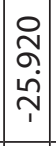 & 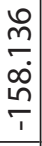 & 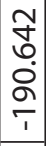 & $\begin{array}{l}0 \\
\stackrel{0}{n} \\
\\
\end{array}$ & $\begin{array}{c}\infty \\
0 \\
0\end{array}$ & $\begin{array}{l}0 \\
0 \\
\infty \\
\infty \\
\infty\end{array}$ & 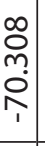 & $\begin{array}{c}\hat{\alpha} \\
\infty \\
\infty\end{array}$ & $\frac{\infty}{\stackrel{\infty}{m}}$ & 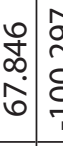 & 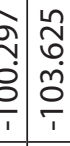 & 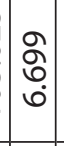 & 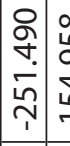 & 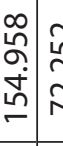 & 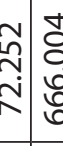 & \\
\hline & & & & & & & & & $\overline{\mathbf{u}}$ & & & & & & & & & & & & & $\bar{a}$ & & $\mathbf{\Sigma}$ & $\bar{P} \overline{\bar{F}}$ & 2 & & \\
\hline
\end{tabular}


Tablo 9'da verilen tahmin sonuçlarına göre, BAG değişkeninin GSYiH üzerindeki etkisi, genel olarak hem yakınsayan hem de ıraksayan ülke gruplarında negatif ve anlamlıdır. Pozitif ve anlamlı derecede etkili olduğu birkaç ülke ise Çin, Gabon, Meksika, Peru, Ürdün ve Venezuela'dır. Buna göre üst orta gelirli ülkelerin OGT'ye düşmemek ve/veya kurtulmak için bağımlılık oranının; yurtiçi tasarrufları azaltma, işsizlik oranlarını yükseltme, kamu harcamalarını artırma gibi büyümeyi yavaşlatıcı etkilerini ortadan kaldırmaları gerekmektedir. ENF değişkeninin GSYiH üzerindeki etkisi, hem yakınsama grubu içinde olan ülkelerde hem de ıraksama özelliği taşıyan ülkelerde negatif ve anlamlıdır. Bostvana, Greneda, Panama, Saint Vincent-Grenadinler'de ise ENF'in etkisi istatistiki açıdan anlamsızdır. OGT'ye düşmenin nedenlerinden biri olan ENF'in büyüme üzerindeki negatif etkisinin ortadan kaldırılması için; üretim maliyetlerinin düşürülmesine, bütçe açıklarının azaltılmasına, ihracat gelirlerinin artırılmasına yönelik politika önlemlerine ağırlık verilmesi önem arz etmektedir. ILK değişkeninin büyüme üzerindeki etkisi; yakınsayan ülkelerden Botsvana, Çin, Dominik Cumhuriyeti, Greneda, Kosta Rika, Malezya, Mauritius, Saint Lucia, Saint Vincent- Grenadinler için pozitif ve anlamlıdır. Iraksayan ülkelerden Belize, Brezilya, Gabon, Tayland, İran ve Ürdün için negatif ve anlamlıdır. Bununla birlikte gelir yakınsaması içinde olan Arjantin, Ekvator, Türkiye ve Venezuela gibi ülkelerde beşeri sermayenin GSYiH üzerindeki etkisi negatiftir. OGT'den çıkmanın en önemli koşullarından biri, ekonomik koşullara uygun nitelikli bireylerin yetiştirildiği ve yüksek gelirli ülkelerde rekabet edebilen etkin eğitim sistemlerinin oluşturulmasıdır. Kamu-özel sektör işbirliği içerisinde oluşturulacak bu sistem sayesinde teknoloji ve bilgiye dayalı üretim yapabilen beşeri sermaye stoku büyümeyi olumlu yönde etkileyebilecektir. Bununla birlikte eğitimin nitel değil, nicel boyutuna önem veren ve faktör donatımına uygun olmayan eğitim sistemlerinin ortaya çıkardığı beşeri sermaye ise üretim düzeyinin düşmesine, kaynak israfının artmasına ve işsizliğin artmasına yol açabilecektir. SER değişkeninin GSYiH üzerindeki etkisi, yüksek gelirli ülkelere yakınsayan Arjantin, Çin, Dominik Cumhuriyeti, Ekvator'da pozitif ve anlamlı; Greneda, Macaristan, Malezya, Saint Lucia, Saint Vincent-Grenadinler, Türkiye, Venezuela ve Malezya'da ise negatif ve anlamlıdır. Iraksayan ülkelerde ise çoğunlukla negatif etkinin baskın olduğu görülmektedir. Yakınsayan ülkelerde negatif etki, bu ülkelerde faktör donatımına uygun olmayan yatırımların yapıldığının, ülkelerin emek yoğun üretimde avantajlarını kaybederken, sermaye yoğun yatıımlara geçişi sağlayacak uygun hamleleri gerçekleştiremediklerinin göstergesi olarak kabul edilebilir. Bu durum, söz konusu üst orta gelirli ülkelerde OGT'nin işlemeye başlamasının kaçınılmaz olacağına işaret etmektedir. OPN değişkeninin büyüme üzerindeki etkisi, yakınsayan ve ıraksayan 16 ülkenin 8'inde negatif; 8'inde ise pozitif etkili ve istatistiki açıdan anlamlıdır. Genel olarak negatif etkinin ıraksayan ülkelerde daha baskın olduğu görülmektedir. Grenada, Saint Lucia, Saint VincentGrenadinler, Türkiye ve Venezuela gibi yakınsayan ülkelerde ise etki pozitif yönlüdür. Yakınsayan üst orta gelirli ülkeler yapısal dönüşüm konusunda geri kalırlarsa OGT'ye düşeceklerdir. Bu durumun ortadan kaldırılması büyük ölçüde dışa açıklığın; verimliliği artırma, ihracatın bileşimini değiştirme, pozitif dışsallık, dış şoklara karşı dayanıklılık, piyasa bütünleşmesi ve rekabet gibi pozitif etkilerinden yararlanmaya yönelik önlemlere ağılık verilmesine bağlıdır. Modelde ele alınan OZG değişkeninin GSYiH üzerindeki uzun dönemli etkisi, yakınsayan ülkelerden Grenada, Kosta Rika ve Mauritius için pozitif; Bostvana, Çin ve Malezya için negatif ve anlamlıdır. Iraksayan ülkelerden Belize, Gabon, İran, Jamaika ve Tunus için pozitif; G. Afrika, Peru ve Tayland için negatif ve anlamlıdır. Bulgular genel olarak değerlendirildiğinde, yakınsayan ve ıraksayan ülkelerin özgürlükler konusunda yeterli başarıyı elde edemedikleri görülmektedir. Özgürlüklerin zayıf kaldığı durumlarda ekonomik büyümede yavaş olmaktadır. OGT'ye düşmemenin ve/veya çıkmanın en önemli koşullarından biri, ekonomik büyümeyi teşvik edecek kurumsal yapının oluşmasını sağlayan özgürlüklerin hakim kılınmasıdır. Böylece özgürlükler, üretim faktörlerinin üretkenliğini arttırarak, kaynak dağılımında etkinliği sağlayarak, rüşvet ve yolsuzlukları azaltarak ve işsizlik oranlarını düşürerek uzun dönemli büyümeyi teşvik edecektir. TAS'ın GSYiH üzerindeki etkisi yakınsayan ülkelerden Dominik Cumhuriyeti, Mauritius; Iraksayan ülkelerden Brezilya ve Tayland için pozitif ve istatistiki açıdan anlamlıdır. Türkiye'nin de içerisinde yer aldığı diğer ülkeler için etkinin yönü negatif ve anlamlıdır. Genel olarak TAS'ın etkisinin negatif olması, yatırımların finansmanı için gerekli olan yurtiçi tasarruf düzeyinin düşük olduğunu göstermektedir. OGT'ye düşmemek ve/veya kurtulmak için tasarrufların artırılması ve ekonomik kırılganlıkları asgari düzeye çekilebilecek etkin bir finansal sistem oluşturulması 
gereklilik arz etmektedir. TLF'nin GSYiH üzerindeki etkisi, genel olarak ıraksayan ülkelerde negatif; yakınsayan ülkelerde pozitif ve anlamlıdır. Bilgi ve iletişim teknolojilerinin göstergesi olan telefon ağı, özellikle OGT'ye yakın ülkeler açısından önem taşımaktadır. Çünkü etkin iletişim ağı, bilgilerin iletiminde uluslararası rekabet ortamı yaratarak, işlem maliyetlerini düşürerek, piyasa bilgilerinin gelişimine ve bilgi yayılımının hızlanmasına katkıda bulunarak ticaret ve ekonomik büyümeyi pozitif etkilemektedir. Hizmet ve bilgiye dayalı ekonomik yapı koşullarına uyum sağlayamayan ülkeler büyük intimalle OGT'ye düşeceklerdir ve bu tuzaktan kurtulmak için çok uzun zaman geçmesi gerekecektir.

\section{SONUÇ VE ÖNERILER}

Bu çalışma kapsamında, Türkiye'nin de içerisinde yer aldığı 28 üst orta gelirli ülkede OGT'nin ve OGT'yi etkileyen faktörlerin belirlenmesi için yakınsama ve panel veri analizleri kullanılmıştır. Üst orta gelirli ülkeler üzerine yapılan mutlak $\beta$ yakınsaması analizinde ele alınan 28 ülkede gelir yakınsamasının söz konusu olduğu tespit edilmiştir. Ortaya konan bu bulgular başlangıç gelir düzeyleri farklı olan ülkelerin gelirlerinin arttığını göstermektedir. Birim kök testine dayalı yakınsama analizinde 28 ülkeden $15^{\prime}$ 'inin yüksek gelirli ülkelere yakınsadığı, 13'ünün ise ıraksadığı belirlenmiştir. Söz konusu bulgular kapsamında ıraksayan ülkelerin OGT'ye düşebilecekleri, yakınsayan ülkelerin ise zaman içinde yeni teknolojileri adapte etme noktasında yetersiz kalmamaları durumunda OGT'ye düşmeyebilecekleri kabul edilmiştir. Panel veri analizleriyle 28 üst orta gelirli ülkede GSYiH ile çalışmada ele alınan 8 bağımsız değişken arasındaki ilişkiden hareketle OGT riski araştırılmıştır. Yapılan tahminler sonucunda, ele alınan bağımsız değişkenlerin tamamının hem yakınsayan hem de ıraksayan ülkelerde ekonomik büyümeyi etkilediği yönünde tespitlere ulaşılmıştır. Etkinin yönünün ise ülkeler bazında farklılık arz ettiği gözlenmiştir. Yüksek gelirli ülkelerden ıraksayan ülkelerin OGT'ye düşme ihtimalinin yüksek olduğu; hızlı büyüme oranlarıyla yüksek gelirli ülkelere yakınsayan ülkelerin ise gerekli yapısal dönüşümleri gerçekleştirme konusunda geri kalmaları durumunda OGT'ye düşecekleri tespit edilmiştir. Gelir yakınsamasına sahip olmasına rağmen yakınsayan ülkelerin sosyoekonomik göstergeler açısından ıraksayan ülke özelliği sergileyebileceğine de rastlanılmıştır. Yani ülkelerin OGT'den kurtulmaları hızlı gelir artışlarından ziyade, yurt içi tasarruf oranlarındaki yükselmeye ve beşeri sermayedeki gelişmelere bağlıdır. Ayrıca dışa açıklık ve ekonomik istikrar gibi temel göstergelerle ifade edilebilecek yapısal dönüşümü gerçekleştirme becerisine sahip olma düzeyi de OGT'ye kurtulma için önemli faktörlerdir.

Sonuç olarak araştırılan literatür ve ortaya konan bu çalışmanın sonuçları itibariyle OGT riskinden kaçınmada yapılması gerekenler şu şekilde sıralanabilir:

- OGT'ye düşmeden yüksek gelirli ülke düzeyine ulaşmak için en önemli koşullardan biri, düşük katma değerli üretimden ileri düzeyde bilgi ve teknoloji kullanan yüksek katma değerli ürünlere geçiş yapmaktır. Doğal kaynak ve ucuz işgücü kullanan endüstrilerde arkadan gelen gelişmekte olan ülkelerin rekabeti ile karşılaşma olasılığı çok yüksektir.

- Rekabetçi üretim yapmanın vazgeçilmez koşullarından biri, insan sermayesi ile ilgilidir. Yeni ürünleri ve teknolojileri geliştirecek olan kalifiye beşeri insanlardır. OGT'ye düşmemiş gelişmekte olan ülkeleri diğerlerinden ayıran temel farklılık, yenilikçi ve yaratıcı ürünler üretmeleridir. Bu da eğitim sistemi ile doğrudan ilişkilidir.

- Eğitim ile yakından ilişkili olarak ihracatın yapısı, teknolojiye dayalı ürün çeşitlendirmesinden oluşturulmalıdır. Teknolojik içeriği yüksek ürünlerin üretilmesi araştırma-geliştirme merkezli, buluş̧̧u ve marka yaratan bir ülke olmakla mümkündür.

- Üretimin etkin organizasyonu, kaynakların etkin kullanımı açısından son derece önemlidir. Özellikle kamunun kaynakları kullanma tercihlerinde rant ekonomisinden uzaklaşıp, serbest rekabet koşullarını gözeten alanlarda yoğunlaşması ve özel sektörü de bu alanlara yönlendirmesi gerekmektedir.

- Kalkınmanın finansmanında sadece dış tasarruflara bağımlı olmak, kırılgan bir ekonomik yapıyı da beraberinde getirmektedir. Bu nedenle yurtiçi tasarruf oranları artırılmalıdır. Böylelikle yatıımların finansmanı yurtiçi kaynaklarla sağlanmış olacaktır. Yurtiçi tasarruf oranlarının artırımasıyla istikrarlı, kırılganlıkların en aza indiği bir ekonomik ortam ve etkin bir finansal sistem oluşturulabilir. Ayrıca başta kamu sektörü 
olmak üzere özel sektör ve hane halklarında verimsiz harcamalar azaltılmalı, bireysel emeklilik sistemleri oluşturulmalı ve kadının işgücüne katılım oranı yükseltilmelidir.

- $\quad$ OGT'den sakınmak için önemli koşullardan biri de ülke içinde bölgesel gelişmişlik farklılıklarının azaltılması ve ikili ekonomik yapının önlenmesidir. Kaynakların verimlilik düzeylerinin ülke içinde tüm bölgelerde birbirine yaklaşması, ülke kaynaklarının daha verimli bir şekilde kullanılmasına imkân verecektir. Bu nedenle, büyümenin sürdürülebilirliği ve rekabetçi bir ekonominin oluşturulması için bölgesel eşitsizlikleri azaltmaya yönelik kamu politikaların uygulanması gerekmektedir.

- Aynı şekilde kaynakların serbest piyasa ortamında üretime en fazla katkı sağlayabilecekleri alanlarda tahsis edilebilmeleri için ekonominin tüm boyutlarında şeffaflık, hesap verebilirlik, hukukun üstünlüğü, ifade ve düşünce özgürlüğü ve demokrasinin tüm kurum ve kurallarıyla hâkim kılınması hedeflenmelidir. Kamu kaynaklarının tüm yatırımcılara serbest piyasa ekonomisinin ruhuna uygun bir şekilde ve rekabetçi bir ortamda tahsis edilmesi, bankacılık sistemindeki kamu kaynaklı ayrıcalıklara son verilmesi gerekmektedir.

- Ülkelerin kendi ihtiyaçları göz önünde bulundurulmak kaydıyla, hızı ekonomik kalkınmada başarı sağlamış ülke tecrübeleri göz ardı edilmemeli ve bu tecrübelerden ders çıkarılarak uygun plan, politika ve stratejiler geliştirilmelidir.

\section{KAYNAKÇA}

Aiyar, S. -Duval, R.-Puy, D. -Wu, Y. ve Zhang, L. (2013) "Growth Slowdowns and the Middle Income Trap" International Monetary Fund (IMF) Working Paper No:13/17.

Aoik, M. (2011) "The Five-Phases of Economic Development and Institutional Evolution in China and Japan" Asian Development Bank Institute, Rapor No: 340.

Baltagi, B. H. (2005) Econometric Analysis of Panel Data, Third Edition, John Wiley\& Sons, England 2005.

Barro, R. J. ve S. M., Xavier (1992) "Convergence", Journal of Political Economy, 100(2):223-251.

Bayar, G.-Güloğlu, B. ve Tokpunar, S. (2011) "Sanayi Sektörü İstihdamının Temel Belirleyicileri ve Dış Ticaret, Türkiye Örneği", Ekonomik Yaklaşım Kongreler Dizisi, 1-22.

Egawa, A. (2013) "Will Income Inequality Cause A Mıddle-Income Trap in Asia?" Bruegel Working Paper Working Paper No:03.

Eichengreen, B. -Park, D. ve Shin, K. (2013) "Growth Slowdowns Redux: New Evidence on the Middle Income Trap" National Bureau of Economic Researh Working Paper No:18673.

Felipe, J. -Abdon, A. ve Kumar, U. (2012) "Tracking the Middle-income Trap: What Is It, Who Is in It, and Why?" Levy Economics Institute of Bard College, Working Paper No:715.
Freedom House (2014) http://www.freedomhouse. org/ (15.05.2014)

Gill, I. ve Kharas, H. (2007) “An East Asian Renaissance Ideas for Economic Growth", World Bank.

Güloğlu, B. ve İvrendi, M. (2010) “Output Fluctuations: Transitory or Permanent? The Case of Latin America", Applied Economics Letters, 17(4):381-386.

Gürsel, S. ve Soybilgen, B.(2013) "Türkiye Orta Gelir Tuzağının Eşiğinde", Betam Araştırma Notu, (13)154:17.

Nahar, S. ve Inder, B. (2002) "Testing Convergence in Economic Growth for OECD Countries", Applied Economics, 34:2011-2022.

Pesaran, M. H. (2004) "General Diagnostic Tests for Cross Section Dependence in Panels", University of Cambridge Working Paper No:0435

, (2006) "Estimation and Inference in Large Heterogeneous Panels wiht A Multifactor Error Structure", Econometrica, 74(4):967-1012.

, (2007) "A Simple Panel Unit Root in the Presence of Cross-Section Dependence" Journal of Applied Econometrics, 22:265-312.

Pesaran, M. H. ve Yamagata, T. (2008) "Testing Slope Homogeneity in Large Panels" Journal of Econometrics, 142:50-93.

Pesaran, M. H.- Ullah, A. ve Yamagata, T. (2008) “A BiasAdjusted LM Test of Error Cross-Section Indepence" Econometrics Journal, 11:105-127. 
Robertson, P.E. ve Longfeng Y. (2013) "On the Existence of a Middle Income Trap, Economics Discussion", The University of Western Australia, Department of Economics, Working Paper No:13/12.

Solow, R. (1956) "A Contribution to the Theory of Economic Growth", The Quarterly Journal of Economics, 70(1):65-94.

Westerlund, J. (2007) "Testing for Error Correction in Panel Data", Oxford Bulletin of Economics and Statistics, 69(6):709-748.

Worldbank (2014) http://data.worldbank.org/about/ country-classifications/world-bank-atlas-method, (18.02.2014)

(2014) http://data.worldbank.org/about/ country-classifications, (18.02.2014) ,http://databank.worldbank.org/

data/views/ variableSelection/selectvariables. aspx? source=world-development-indicators. $(01.12 .2014)$

http://data.worldbank.org/indicator/ SP.POP.DPND.OL. (01.12.2014)

Yeldan, E. -Taşçı, K. -Voyvoda, E. ve Özsan, M. E. (2012) "Orta Gelir Tuzağından Çıkış: Hangi Türkiye? Cilt 1: Makro/Bölgesel/Sektörel Analiz" Türk Girişim ve İş Dünyası Konfederasyonu (Türkonfed).

Yıldırım, K.- Mercan, M. ve Kostakoğlu, S. F. (2013) "Satın Alma Gücü Paritesinin Geçerliliğinin Test Edilmesi: Zaman Serisi ve Panel Veri Analizi", Eskişehir Osmangazi Üniversitesi İktisadi İdari Bilimler Fakültesi Dergisi, 8(3):75-95. 